\title{
8 The Marine Jellyfish Model, Clytia hemisphaerica
}

\author{
Sophie Peron, Evelyn Houliston and Lucas Leclère
}

\section{CONTENTS}

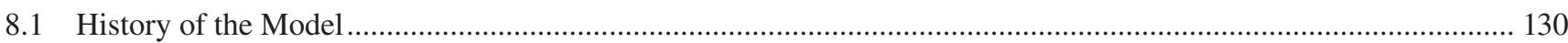

8.1.1 Early Studies on Clytia hemisphaerica Anatomy and Development........................................................ 130

8.1.1.1 First Descriptions of Clytia Embryonic Development................................................................ 130

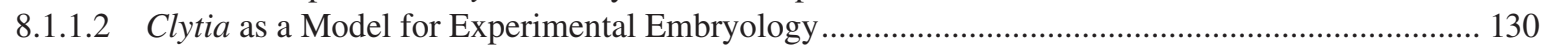

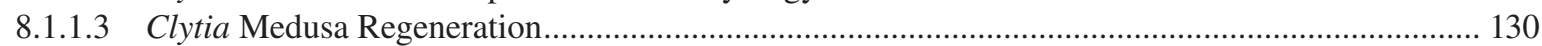

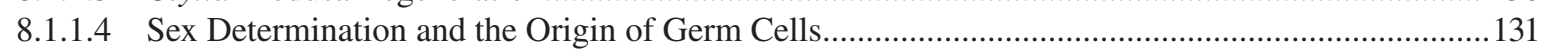

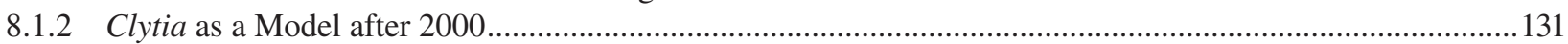

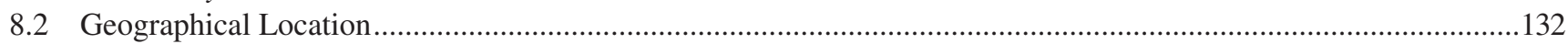

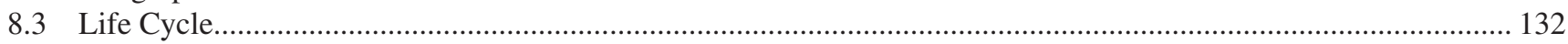

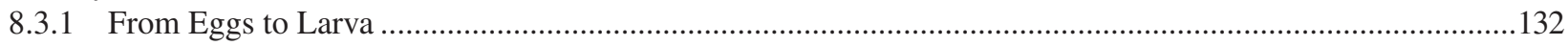

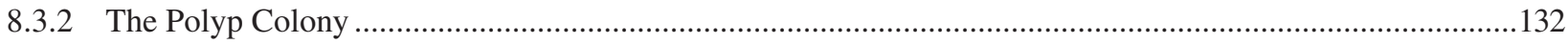

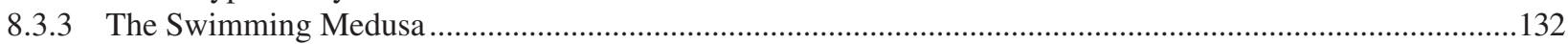

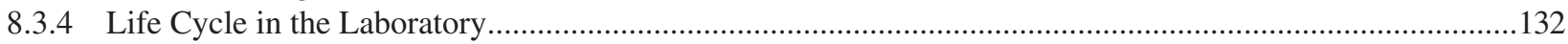

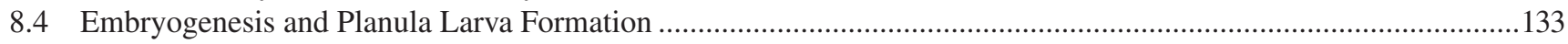

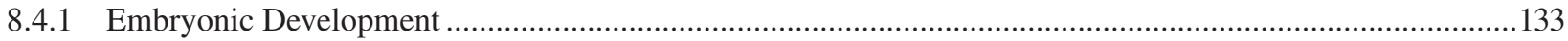

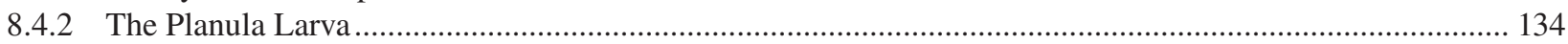

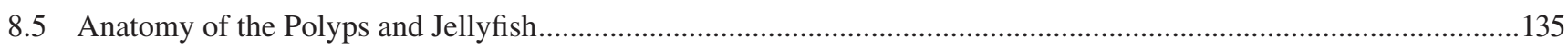

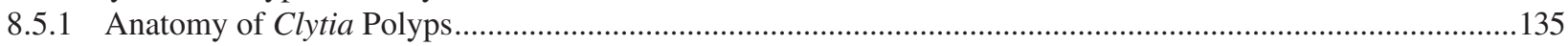

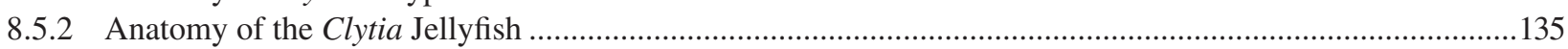

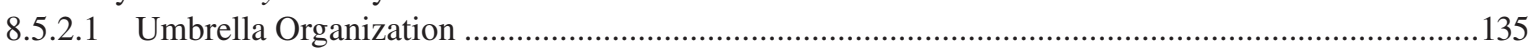

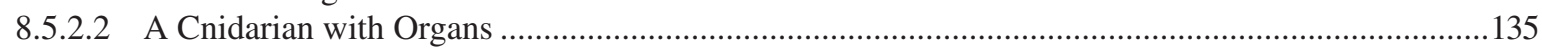

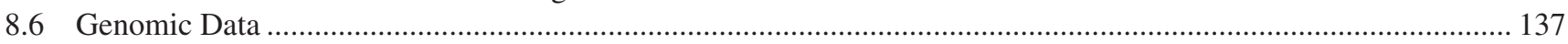

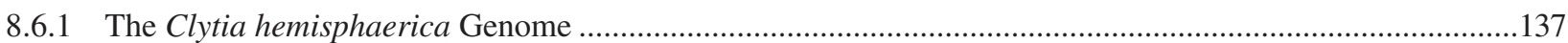

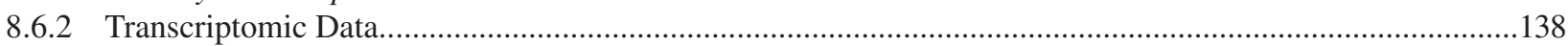

8.7 Functional Approaches: Tools for Molecular and Cellular Analyses.....................................................................138

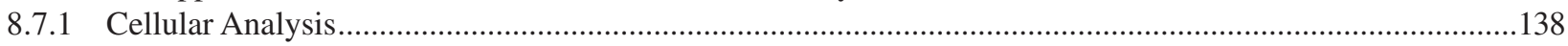

8.7.2 Gene Function Analysis during Embryogenesis and Oocyte Maturation...................................................138

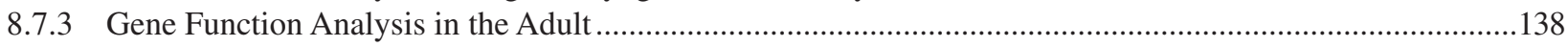

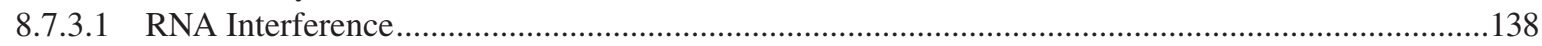

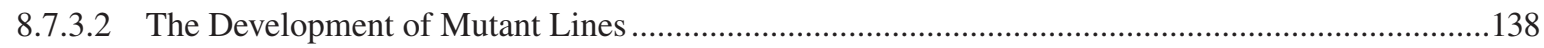

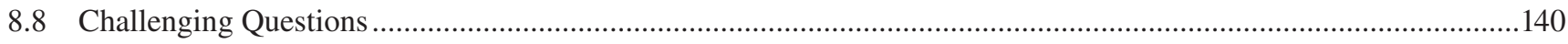

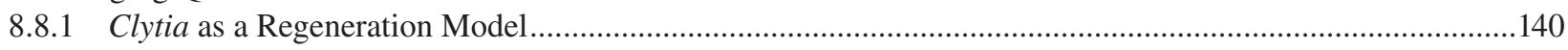

8.8.1.1 How Is the Cellular Response Controlled during Regeneration? ....................................................140

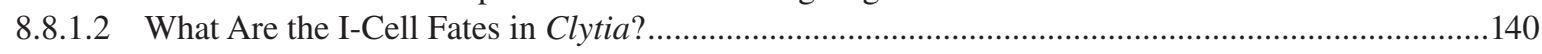

8.8.1.3 How Are Mechanical Cues and Signaling Pathways Integrated? ..................................................142

8.8.2 Regulation of Behavior and Physiology by Environmental Cues................................................................. 142

8.8.2.1 Which Bacterial Cues Induce Settlement of the Planula? Which Molecular
Mechanisms Are Triggered? .............................................................................................. 142

8.8.2.2 Is There a Physiological Link between Gametogenesis and Nutrition? ........................................... 142

8.8.2.3 How Does Feeding Availability Regulate Growth of Polyps and Medusa? .................................... 142

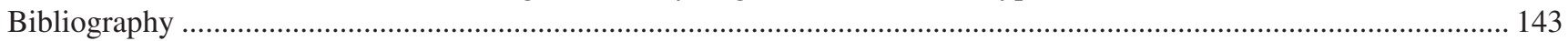




\subsection{HISTORY OF THE MODEL}

Classical "model" organisms (such as mouse, drosophila, nematode, etc.) have contributed a huge amount of knowledge in biology but represent only a small fraction of the diversity of organisms. Marine animals are very diverse in term of morphology and physiology and cover a wide range of taxa. Therefore, they can make a valuable contribution to research, both for addressing biological processes and evolutionary questions.

This chapter presents Clytia hemisphaerica, a jellyfish with growing interest as an experimental model. This species can be cultured in the lab in reconstituted sea water, allowing use in any laboratory and a constant supply in animals. First the history of Clytia as an experimental model and the characteristics of Clytia life stages will be presented. Then diverse experimental tools, currently available and still in development, will be described, before presenting some biological questions that can be addressed using Clytia.

Due to their phylogenetic position as a sister group to the bilaterians, cnidarians are a valuable study group for addressing evolutionary questions. Cnidarians are divided into two main clades: the anthozoans, comprising animals only living as polyps for the adult form, and the medusozoans, characterized by the presence of the jellyfish stage in the life cycle (Collins et al. 2006). Clytia hemisphaerica (Linnaeus 1767) is a medusozoan species of the class Hydrozoa, the order Leptothecata (characterized by a chitinous envelop protecting the polyps and by the flat shape of the jellyfish) and the family Clytiidae (Cunha et al. 2020). Its life cycle is typical of hydrozoans, alternating between two adult forms: the free-swimming jellyfish (= medusa) and asexually propagating polyp-forming colonies.

Clytia hemisphaerica has long been recognized as a valuable research organism for studying several aspects of hydrozoan biology thanks to its ease of culture; its total transparency; and its triphasic life cycle, including a medusa stage. This last feature distinguishes it from the other main cnidarian model organisms (Hydra, Nematostella and Hydractinia). It is thus possible to study in Clytia hemisphaerica complex characters absent from the polyp-only model species, notably: striated muscles; a well-organized nervous system condensed in two nerve rings at the margin of the umbrella; and welldefined and localized organs: the gonads, the manubrium regrouping the mouth and the stomach and the tentacle bulbs.

\subsubsection{Early Studies on Clytia hemisphaerica Anatomy and DeVelopment}

Clytia hemisphaerica was referred to in earlier literature under a number of synonyms, such as Clytia johnstoni (in: Alder 1856), Clytia laevis (in: Weismann 1883), Clytia viridicans (in: Metchnikoff 1886), Phialidium hemisphaericum (in: Bodo and Bouillon 1968) or Campanularia johnstoni (in: Schmid and Tardent 1971; Schmid et al. 1976). Clytia, when used alone in this chapter, will refer to the species Clytia hemisphaerica.

\subsubsection{First Descriptions of Clytia Embryonic Development}

The first detailed description of embryogenesis in Clytia was conducted by Elie Metschnikoff in the late 19th century in the marine stations of Naples and Villefranche-sur-Mer (Metchnikoff 1886). In his book Embryologische studien an Medusen (1886), he described and compared the development and larva morphology of several medusa species from these sites, including Clytia hemisphaerica (= Clytia viridicans). Lacassagne (1961) performed histological studies, comparing planulae belonging to the family of "calyptoblastiques à gonophores" including Clytia. Seven years later, Bodo and Bouillon (1968) published a description of the embryonic development of five hydromedusae from Roscoff. Their study contains a detailed description of Clytia planulae, particularly their cell types and mode of settlement.

\subsubsection{Clytia as a Model for Experimental Embryology}

A distinct but closely related species, Clytia gregaria (= Phialidium gregarium), abundant on the west coast of the United States, was used extensively by the embryologist Gary Freeman and played an important part in the history of cnidarian experimental embryology (Freeman 1981a; Freeman 1981b; Freeman 2005; Freeman and Ridgway 1987; Thomas et al. 1987). Through cutting and grafting experiments using embryos and larvae from wild caught medusae, Freeman investigated the establishment of polarity in Clytia gregaria larvae, termed antero-posterior (AP) at that time but now commonly referred to as oral-aboral (OA). He determined i) that isolated parts of the cleaving embryo develop into normal planulae; ii) that they conserve their original antero-posterior axis (Freeman 1981a); iii) that the position of the posterior (oral) pole can be traced back to the initiation site of the first cleavage (Freeman 1980); and iv) that during gastrulation, interactions between the parts of the embryo determine the axis of the planula (Freeman 1981a). This work highlighted the precise regulation of Clytia embryogenesis and its flexibility, allowing the development of a correctly patterned planula even if a part of the embryo is missing.

\subsubsection{Clytia Medusa Regeneration}

The Clytia medusa, like its embryo, can cope with various types of injuries by repatterning and restoration of lost parts. This marked ability to self-repair and regenerate is another particularity that raised interest in early studies. Among cnidarians, the regenerative abilities of polyps (e.g. Hydra, Hydractinia, Nematostella) are well known (Amiel et al. 2015; Bradshaw et al. 2015; DuBuc et al. 2014; Galliot 2012; Schaffer et al. 2016). The huge regenerative abilities of Hydra were first documented in the 18th century by Trembley in an attempt to determine whether Hydra belonged to plants or animals (1744). In contrast, jellyfish were considered to have lesser abilities due to their greater anatomic complexity (Hargitt 1897). Compared to the literature about the regeneration abilities of the polyps, 
relatively few studies documented the abilities of hydrozoans and scyphozoans jellyfish (Abrams et al. 2015; Hargitt 1897; Morgan 1899; Okada 1927; Schmid and Tardent 1971; Schmid et al. 1982; Weber 1981; Zeleny 1907).

Neppi (1918) documented the regeneration abilities of wild-caught Clytia (Phialidium variabile). She concluded that fragments of the umbrella can restore their typical bell shape, and the manubrium and radial canals are restored if they are missing from the fragment, as seen also for other hydrozoan jellyfish (Gonionemus: Morgan 1899; and Obelia: Neppi 1918). More detailed studies were performed in the 1970s by Schmid and collaborators (Schmid and Tardent 1971; Schmid 1974; Schmid et al. 1976; Schneider 1975; Stidwill 1974). These researchers documented the selfrepair and regeneration abilities of wild-caught $C$ lytia caught near Villefranche and Banyuls marine stations (Schmid and Tardent 1971). Like Neppi in 1918, they observed that a fragment of the umbrella is able to restore the circular jellyfish shape in a quick and stereotypical process. Any missing organs (manubrium, canals and gonads) then regenerate, the manubrium being the first organ to reform. While the circular shape and missing organs are consistently restored, they found that the original tetraradial symmetry is not necessarily reestablished (Schmid and Tardent 1971). Subsequent studies focused on the mechanisms regulating manubrium regeneration (Schmid 1974; Schmid et al. 1976). They first looked for an induction/inhibition system based on morphogens, similar to that described in Hydra. The results of grafting experiments suggested that such diffusing molecules in the tissue are not responsible for guiding the regeneration of the manubrium in Clytia (Schmid 1974; Schmid et al. 1976; Stidwill 1974). An alternative hypothesis coming from this work was that tension forces generated by the muscle fibers and the underlying mesoglea are important in patterning during regeneration (Schmid et al. 1976; Schneider 1975). Further regeneration studies on jellyfish were performed on Podocoryna carnea and focused on the ability of its striated muscle cells to transdifferentiate after isolation from the jellyfish (Schmid et al. 1982). Clytia was not used further to study regeneration until its establishment as an experimental lab-cultured model species (see Section 8.8.1).

\subsubsection{Sex Determination and the Origin of Germ Cells}

In cnidarian life cycles, asexual and sexual reproduction often coexist. In medusozoans, the polyp stage ensures asexual reproduction, whereas the jellyfish is the sexual and dispersive form. Some medusae, including Clytia mccrady, a leptomedusa found in the Atlantic ocean and Mediterranean sea, are also able to generate medusae asexually through a budding zone, called the blastostyle, positioned in the place of the gonads (Carré et al. 1995). Carré et al. (1995) showed that, in this species, asexually reproducing jellyfish produce asexual jellyfish.

The origin of germ cells and the mode of sex determination were studied in Clytia hemisphaerica by Carré and Carré (2000). Medusae produced from newly established polyp colonies kept at $15^{\circ} \mathrm{C}$ were mostly male, whereas most of those produced at $24^{\circ} \mathrm{C}$ were female. However, some medusa produced at $24^{\circ} \mathrm{C}$, then raised at $15^{\circ} \mathrm{C}$, became male. These findings indicate that sex is not determined genetically. Carré and Carré proposed that two populations of germ cell precursors could coexist in newly released Clytia medusa: a dominant female population, temperature sensitive and inactivated at $15^{\circ} \mathrm{C}$, and a male population, active at low temperatures (2000). In Hydra, it has been shown that grafting of male germ cells in a female polyp leads to the masculinization of the polyp. The male germ cells migrate into the polyp and proliferate, whereas the existing female germ cells are eliminated (Nishimiya-Fujisawa and Kobayashi 2012). In Clytia, the male and female germ cell populations could be competing as well, with low temperature favoring male germ cells (Siebert and Juliano 2017).

\subsubsection{Clytia as a Model after 2000}

Following the suggestion of Danielle Carré, Evelyn Houliston started in 2002 Clytia cultures in the marine station of Villefranche-sur-Mer, initially to study egg and embryo polarity in this transparent animal. Daily spawning of males and females and external fertilization allowed easy access to all developmental stages for microscopy and experimentation. The culture system is now standardized (Lechable et al. 2020), and different inbred lines have been established by successive self-crossing, starting from a founder colony " $Z$ " obtained from crossing wild medusa collected in the bay of Villefranche. A male colony resulting from three successive self-crossing $(\mathrm{Z} 4 \mathrm{C})^{2}$ was used for genome sequencing (Leclère et al. 2019). Several Z-derived male and female lines are currently used in Villefranche (Houliston et al. 2010; Leclère et al. 2019). Medusae from a given line are produced asexually from a polyp colony and therefore are genetically identical.

Clytia started as a model for developmental studies from 2005. Until 2010, it was mostly studied in two laboratories, in Villefranche-sur-Mer and Paris. The main research topics were oogenesis, embryonic patterning and polarity, evolution of developmental mechanisms, nematogenesis and gametogenesis (Amiel et al. 2009; Amiel and Houliston 2009; Chevalier et al. 2006; Chiori et al. 2009; Denker et al. 2008a; Denker et al. 2008b; Denker et al. 2008c; Derelle et al. 2010; Forêt et al. 2010; Fourrage et al. 2010; Momose et al. 2008; Momose and Houliston 2007; Philippe et al. 2009; Quiquand et al. 2009, reviewed by Houliston et al. 2010; Leclère et al. 2016). Tools have been progressively developed for imaging during embryogenesis and in the adult, and for gene function analysis in the embryo (injection of Morpholino oligonucleotides [MOs] or mRNAs into the egg or the embryo: Houliston et al. 2010) and in the adult (gene knock out with CRISPR-Cas9: Momose et al. 2018).

Clytia studies continue in Villefranche, with recently published work concerning, for instance, oocyte maturation (Quiroga Artigas et al. 2020; Quiroga Artigas et al. 2018), embryogenesis (Kraus et al. 2020; van der Sande et 
al. 2020) and regeneration (Sinigaglia et al. 2020). Michael Manuel and colleagues in Paris also worked extensively on Clytia until recently, notably focusing on the jellyfish tentacle bulb (Condamine et al. 2019; Coste et al. 2016; Denker et al. 2008c). The team of Jocelyn Malamy from Chicago University has started to work on wound healing in Clytia. They uncovered two healing mechanisms (actomyosin cable and lamelipods crawling) and developed a DIC microscopy system allowing visualization of individual cell movements (Kamran et al. 2017; Malamy and Shribak 2018). Other published articles on Clytia include the work of Ulrich Technau's group (Gur Barzilai et al. 2012; Kraus et al. 2015; Steinmetz et al. 2012), notably demonstrating the convergence of hydrozoan and bilaterian striated muscles, and from Noriyo Takeda identifying the maturation-inducing hormones (MIHs) in Clytia and Cladonema jellyfish (Takeda et al. 2018). Other groups worldwide are starting to adopt Clytia for their research.

\subsection{GEOGRAPHICAL LOCATION}

Clytia hemisphaerica is a cosmopolitan jellyfish species. Its presence has been documented in many places, including the Mediterranean sea (between September and March in Villefranche; Carré and Carré 2000), Brittany (in Roscoff in 1968, particularly during summer and fall; Bodo and Bouillon 1968), the English Channel (Lucas et al. 1995), as well as Japan (= Clytia edwardsi) (Kubota 1978) and the US north Pacific coast (Roosen-Runge 1962).

Clytia undergo light-dependent diel vertical migrations following a day/night cycle, like many hydrozoan jellyfish (Mills 1983). The physiological, ecological and evolutionary relevance of this daily migration remains to be studied. In laboratory conditions, Clytia hemisphaerica medusae spawn two hours after a dark-light transition after migrating to the surface of the tank, matching the morning spawning of local populations (Quiroga Artigas 2017). Variant spawning patterns have been reported at other locations, for instance, at dawn and dusk for Clytia hemisphaerica in Friday Harbor (US north Pacific coast) (Roosen-Runge 1962).

\subsection{LIFE CYCLE}

Clytia belongs to the hydrozoan class and exhibits the typical life cycle, alternating between a planula larva, benthic polyp and pelagic medusa (Figure 8.1).

\subsubsection{From Eggs to Larva}

Gametes are released daily by male and female medusae, triggered by light following a dark period (Amiel et al. 2010). The fertilized eggs develop into a torpedo-shaped planula larva, swimming by ciliary beating (Figure 8.1). Three days after fertilization, the larva settles on a substrate by the aboral pole. Metamorphosis into a primary polyp is induced by bacterial biofilms in natural conditions and can be triggered in the laboratory by the peptide GLW-amide on glass or plastic slide (Lechable et al. 2020; Piraino et al. 2011; Takahashi and Hatta 2011). During metamorphosis, the larva flattens on the substrate, and all the polyp structures are formed de novo. The oral part of the planula will give rise to the hypostome (mouth) of the polyp (Freeman 2005).

\subsubsection{The Polyp Colony}

The polyp colony is the asexually propagating, benthic stage of the life cycle. The body of the primary polyp is composed of a tube with a cylindrical shape, surmounted by a hypostome, surrounded by tentacles. After the first feeding, the colony starts to form by the growth of a stolon, a tubular structure spreading on the substrate, at the foot of the primary polyp. Other polyps are formed by lateral budding of the stolon, spaced by distances of 3 to $4 \mathrm{~mm}$ (Hale 1973). The gastrovascular system is shared between all the zooids through the stolon, allowing specialization of the zooids in two types: the gastrozooids catch and digest prey, and the gonozooids produce jellyfish by lateral budding (Figure 8.1). Well-fed and cleaned Clytia colonies show unlimited growing capacity, continuously extending their stolons and budding new zooids. The life span of a Clytia colony is unknown. In our lab culture conditions, the oldest colonies are 15 years old and show no obvious sign of aging.

\subsubsection{The Swimming Medusa}

Polyp colonies release hundreds of clonal and genetically identical jellyfish daily, produced by the gonozooids (Figure 8.1). Budding of the jellyfish starts with the growth of ectoderm and endoderm of the polyp wall. A group of cells then appears to delaminate from the distal ectoderm of the bud, forming the entocodon, a cell layer giving rise to the striated muscle of the medusa sub-umbrella. The ectoderm will give rise to the exumbrella, the external part of the velum and the tentacle epidermis, whereas the endoderm forms the gastrovascular system and the internal tentacular epithelium (Kraus et al. 2015). The formed jellyfish is folded inside the gonozooid and unfolds after release. The jellyfish are gonochoric. As mentioned, sex is influenced by the temperature of growth of the young polyp colony (Carré and Carré 2000). Depending on feeding, jellyfish reach sexual maturity in two to three weeks after release (Figure 8.1). Clytia jellyfish reach an adult size of 1 to 2 centimeters of diameter and live for up to two months.

\subsubsection{Life Cycle in the Laboratory}

Clytia cultures can be maintained in glass beakers containing filtered sea water, but a more convenient tank system has now been developed-see Lechable et al. (2020) for full details. Medusa and polyps are kept in kreisel tanks with circulating reconstituted sea water. Temperature and salinity are controlled. Jellyfish are fed twice a day with hatched Artemia nauplii. The use of artificial sea water allows culture of Clytia in inland labs. 


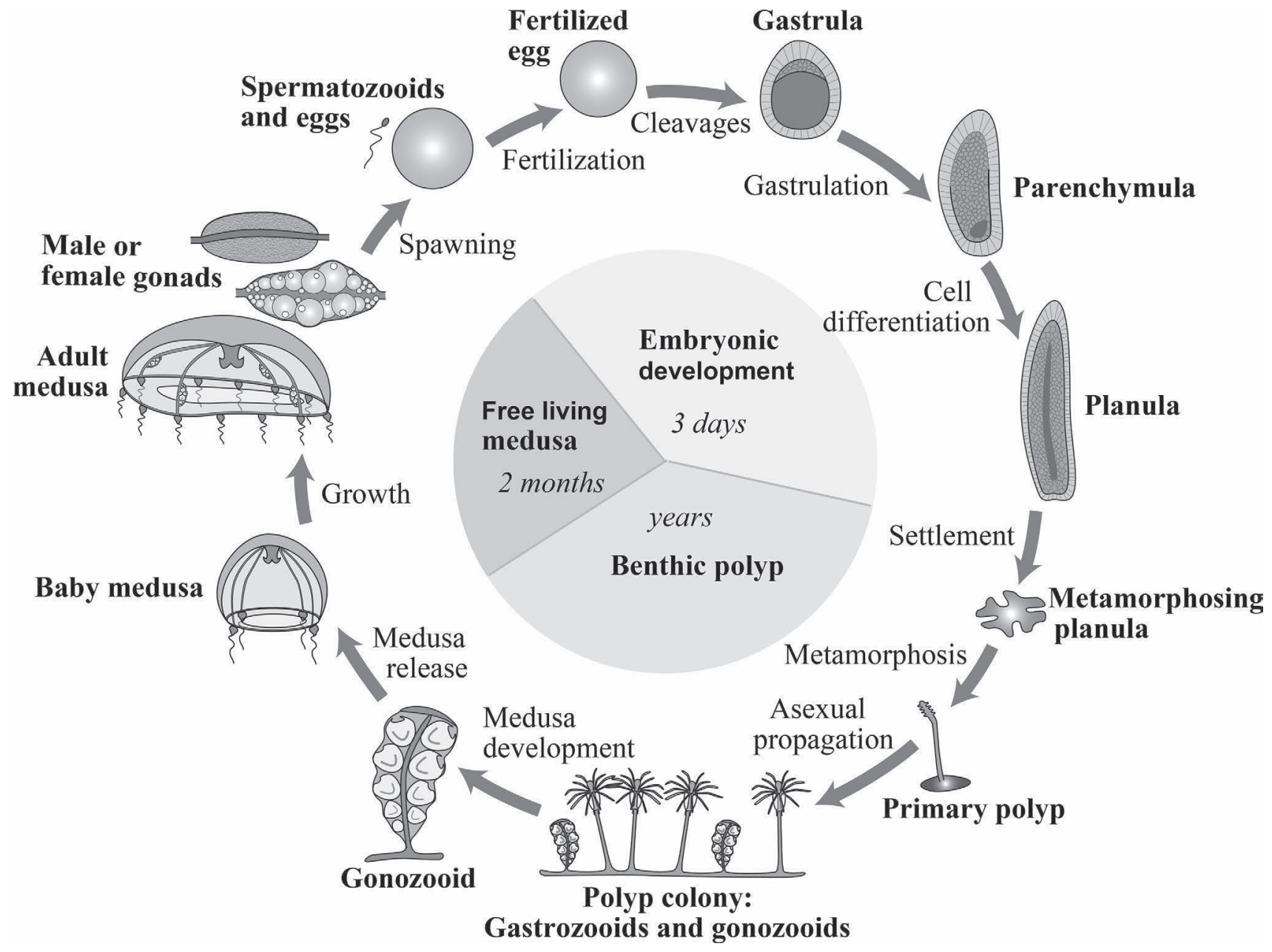

FIGURE 8.1 The triphasic life cycle of Clytia hemisphaerica. After fertilization, the embryo develops into a swimming planula larva in three days. The larva settles on a substrate and undergoes metamorphosis. Growth of the stolon from the primary polyp and budding of new zooids on the stolon lead to the formation of a colony composed of two types of polyps: gastrozooids ensure feeding of the colony, and gonozooids produce the medusae by asexual budding. Male and female medusae are mature two to three weeks after release and spawn gametes after a light cue.

\subsection{EMBRYOGENESIS AND PLANULA LARVA FORMATION}

\subsubsection{Embryonic DeVelopment}

After spawning and fertilization, the egg undergoes successive divisions until formation of a monolayered blastula (Figure 8.2A). The first division occurs $50 \mathrm{~min}$ after fertilization at $18^{\circ} \mathrm{C}$, each following division cycle taking around 30 minutes (Kraus et al. 2020). The initiation site of the first cleavage at the animal pole of the egg marks the site of cell ingression during gastrulation and will give rise to the future oral pole of the larva (Freeman 1981b). Polarity is specified by maternal determinants localized in the oocyte: mRNAs coding for Wnt3 and Fz1 (Frizzled 1) at the animal pole which promote oral fate of the planula and for $\mathrm{Fz} 3$ at the vegetal pole which promote aboral fate, via the activation of the Wnt canonical pathway in the future oral territory (Momose et al. 2008; Momose and Houliston 2007).
The blastula stage begins at the 32-cell stage, with the appearance of the blastocoel. At about seven hours postfertilization (hpf), the cells of the blastula elongate and become polarized along their apico-basal axes, forming an epithelium with apical cell-cell junctions. In parallel to this epithelialization, the diameter of the embryo reduces as the thickness of the blastoderm increases, a process called "compaction" (Kraus et al. 2020). At the late blastula stage, cilia appear on the apical surface of the embryo. Gastrulation starts at around $11-12 \mathrm{hpf}$ at $18^{\circ} \mathrm{C}$. Individual cells detach from the blastoderm at the future oral pole and fill the blastocoel by migrating inside, where they will form the endoderm (Figure 8.2A, B, C). This mode of gastrulation is called unipolar cell ingression (Byrum 2001). During gastrulation, the embryo elongates along the oral-aboral axis by a cell intercalation mechanism dependent on planar cell polarity (Momose et al. 2012). Gastrulation is completed at around $20-24 \mathrm{hpf}$ at $18^{\circ} \mathrm{C}$ (Kraus et al. 2020). The resulting parenchymula has an elongated shape, but the endoderm 

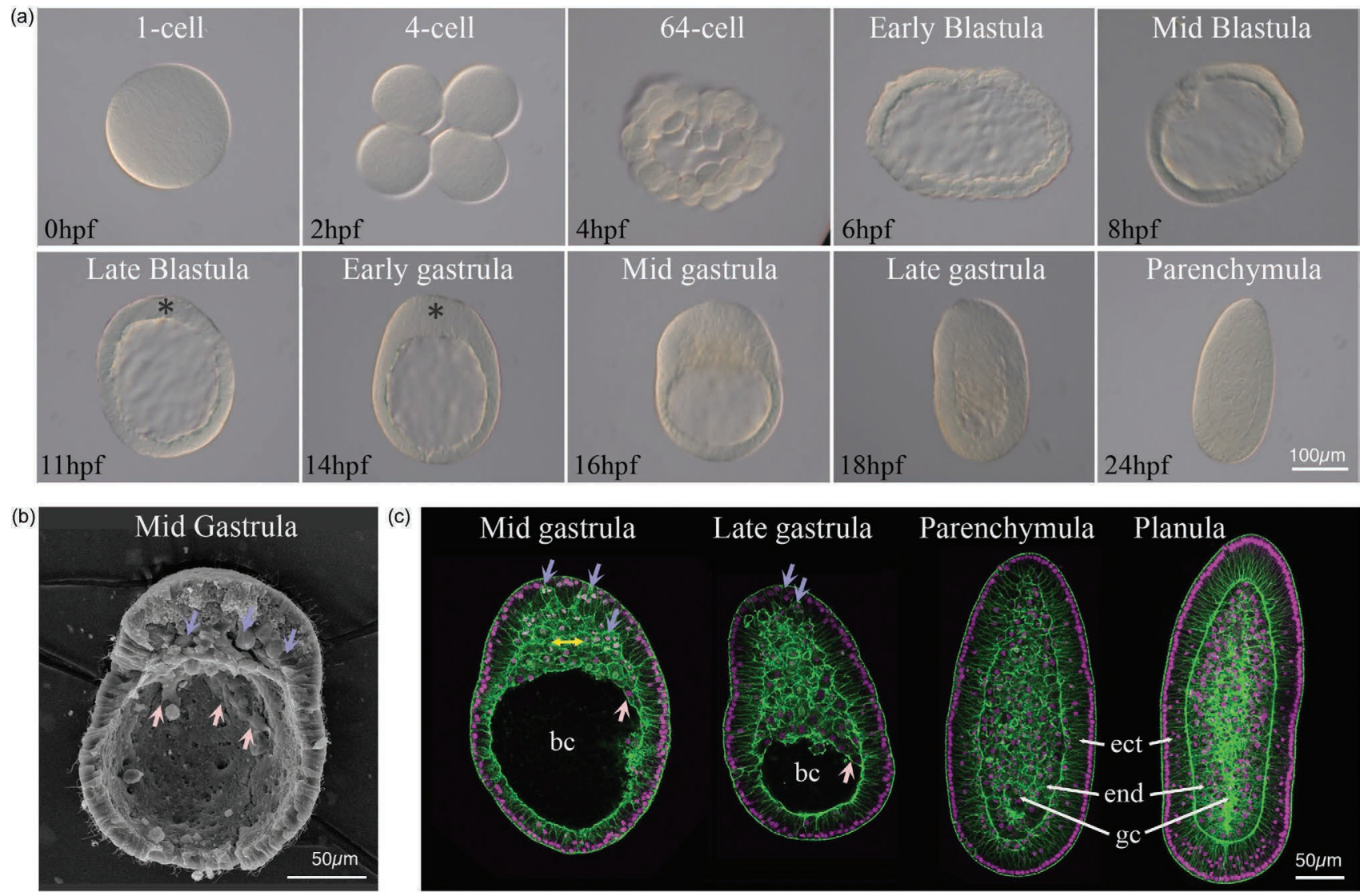

FIGURE 8.2 Clytia embryonic development. (a) DIC images of successive developmental stages until the end of gastrulation (Parenchymula stage). After fertilization, successive cleavage divisions increase the number of cells during the first hours, forming a hollow blastula. Between early and mid-blastula stages, epithelization of the blastoderm is accompanied by "compaction", that is, reduction in embryo diameter. The embryo oral pole is first visible as local cell layer thickening ahead of gastrulation (asterisks). Gastrulation proceeds by unipolar cell ingression from around the oral pole. Ingressed cells colonize the blastocoel, providing the future endoderm. Concomitantly, the embryo elongates. $\mathrm{hpf}=$ hours post-fertilization at $18^{\circ} \mathrm{C}$. (b) Scanning electron micrograph of a mid-gastrula embryo split perpendicular to the oral-aboral axis to reveal the inner face of the blastocoel. Purple arrows show examples of ingressing cells at the oral pole and pink arrows ingressed cells with mesenchymal morphology migrating toward aboral pole. (c) Confocal images of embryos and planulae following staining of cell contours with phalloidin (green) and nuclei with Hoechst dye (magenta), as described in Kraus et al. (2020). Purple and pink arrows again show ingressing and migrating cells. The double-headed yellow arrow shows a region where lateral intercalation of ingressed cells is likely contributing to embryo elongation. gc: gastrocoel, ect: ectoderm, end: endoderm. $(\mathrm{a}-\mathrm{c})$ Gastrula and planulae are all oriented with the oral pole at the top. ([a] Adapted from van der Sande et al. 2020; [b] from Kraus et al. 2020.)

is not differentiated. A thin extracellular matrix layer separating the ectoderm and the endoderm (basal lamina) starts forming at the aboral pole, and a central gastric cavity progressively develops between one and two days after fertilization (Figure 8.2A, C). By two days after fertilization, the ectodermal and endodermal epithelia of the planula larva are fully developed and totally separated by the basal lamina, and the gastrocoel is complete (Figure 8.2C). Cell types continue to differentiate until the larva can metamorphose at around three days after fertilization.

\subsubsection{The Planula Larva}

The larva has a simple morphology. It has a torpedo shape and swims with the aboral pole in front, thanks to coordinated beating of the cilia on the ectoderm cells. Cilia orientation is coordinated by planar cell polarity along the aboral-oral axis, the protein Strabismus being located to the aboral side of each cell and Fz1 on the oral side (Momose et al. 2012).

The planula larva of Clytia is lecitotroph and has few cell types. The ectoderm and endoderm are composed of a typical cnidarian cell type called myoepithelial cells (epithelial cells with basal muscle fibers), nerve cells (including neurosensory and ganglion cells; Thomas et al. 1987), nematocytes (stinging cells used for prey capture and defense) (Bodo and Bouillon 1968) and interstitial stem cells called i-cells (see the following). Secretory cells and i-cells are scattered in the endoderm, with the secretory cells being also present in the aboral ectoderm (Bodo and Bouillon 1968; Leclère et 
al. 2012). Nematoblasts start to differentiate in the endoderm of the planula from $24 \mathrm{hpd}$ before migrating to the ectoderm (Bodo and Bouillon 1968; Ruggiero 2015).

I-cells are multipotent stem cells (Bosch and David 1987), found only in hydrozoans. They are small round cells with a high nucleo-cytoplasmic ratio and are localized in the spaces between the epitheliomuscular cells. They have been well investigated in Hydra, where they have been shown to give rise to the nematocytes (Slautterback and Fawcett 1959), nerve cells (Davis 1974), gland cells (Bode et al. 1987) and gametes (Nishimiya-Fujisawa and Kobayashi 2012; reviewed in: Bode 1996; Bosch et al. 2010). I-cells in Clytia can be detected by their expression of the stem cell markers Nanosl, Piwi, Vasa and PL10 (Leclère et al. 2012). These genes are also expressed in the precursors of somatic derivatives, such as nematocytes (Denker et al. 2008c), and in germ cells. In Clytia, i-cells appear during embryonic development (Leclère et al. 2012). Maternal mRNAs for the stem cells markers Nanos1 and Piwi are concentrated in the egg next to the female pronucleus at the animal pole. During the cleavage stages, these mRNAs appear to be segregated into animal blastomeres. During gastrulation, expression of Nanosl and Piwi is taken up by cells positioned at the site of cell ingression that are internalized with the future endoderm. In the three-day-old planula, Nanos 1 and Piwi expressing cells are present in the endodermal layer and have typical i-cell morphology (Leclère et al. 2012). The developmental potential of i-cells in different Clytia life stages remain to be investigated.

\subsection{ANATOMY OF THE POLYPS AND JELLYFISH}

\subsubsection{Anatomy of Clytia Polyps}

The two types of polyps composing the colony have clear morphological differences linked to their specialized functions in the colony. The feeding polyps or gastrozooids are very similar to the primary polyp (described in Section 8.3.2). They are protected by a cup-shaped chitinous structure called the hydrotheca. The medusa budding polyps, or gonozooids, do not have a mouth and receive nutrients digested by the gastrozooids through the stolon network. They are completely enveloped by a chitinous gonotheca. They possess an internal structure called the gonophores, producing the medusae by lateral budding. The base of all zooids is attached to the stolon, composed from outside to inside by the perisarc (a chitinous exoskeleton), an ectodermal epithelium and an endodermal epithelium surrounding the gastric cavity that distributes nutrients throughout the whole colony.

Polyps are composed of the following cell types: myoepithelial cells (ectodermal and endodermal), nerve cells, nematocytes (only ectodermal) and gland cells. I-cells are found in the stolon. Nematocytes differentiate in the stolon and then migrate into the polyp bodies (Leclère 2008; Weiler-Stolt 1960).

\subsubsection{Anatomy of the Clytia Jellyfish}

Compared to the polyp, the jellyfish has a more complex anatomy, with well-organized smooth and striated muscle, organized nervous system, balance organs (statocysts) and well-defined organs.

\subsubsection{Umbrella Organization}

The Clytia jellyfish body exhibits tetraradial symmetry (Figure 8.3A, B). The oral-aboral axis is the sole axis of symmetry at the scale of the whole medusa. The bell-shaped umbrella is composed of two parts, the convex exumbrella and the concave subumbrella, separated by a thick acellular layer called the mesoglea (Figure 8.3C). The exumbrella is composed of a monolayer of epidermal cells (Kamran et al. 2017). Different cell populations are present in the subumbrella: i) an epithelium lining the mesoglea; ii) epidermal cells with myofilaments forming radial smooth muscle cover the entire subumbrella, responsible for the folding of the umbrella to bring prey to the mouth and for shock-induced protective crumpling; and iii) striated circular muscle fibers responsible for the contraction of the umbrella and the swimming movements, located between the two body layers in a band around the bell margin (Figure 8.3C, D) (Sinigaglia et al. 2020). At the periphery of the umbrella, an extension of the umbrella called the velum increases propulsion efficiency. This tissue membrane is a characteristic of hydrozoan jellyfish (Brusca et al. 2016). Medusa growth involves addition of new tissue to the peripheral region of the bell (Schmid et al. 1974).

Movements of the medusa are coordinated by a diffuse nerve net reaching all parts (Figure 8.3E, F). Two nerve rings are located at the margin of the bell. The external nerve ring integrates sensory information, while the inner nerve ring is responsible for coordinating contraction (Houliston et al. 2010; Satterlie 2002). Statocysts (balance sensory organs) located between the tentacle bulbs likely ensure orientation in the water column (Figure 8.3G). They comprise a vesicle of ectoderm with ciliated internal walls enclosing a statolith made of magnesium and calcium phosphate $\left(\mathrm{MgCaPO}_{4}\right)($ Chapman 1985; Singla 1975).

\subsubsection{A Cnidarian with Organs}

From the center of the subumbrella hangs the manubrium, which is the feeding organ (Figure 8.3B, H). At its distal end is located the cross-shaped mouth, connected to the gastric cavity at the base. The outer layer of the manubrium comprises a layer of epidermal epitheliomuscular cells continuous with the subumbrella radial muscle cell layer. A distinct inner gastroderm layer lines the gastric cavity and contains both epithelial cells and populations of gland cells expressing different enzymes for extracellular digestion (Peron 2019). Four pools of i-cells positioned at the base of the manubrium likely generate the loose nerve net that lies between the gastroderm and the epiderm, as well as nematocytes mostly found concentrated on the manubrium lips. 


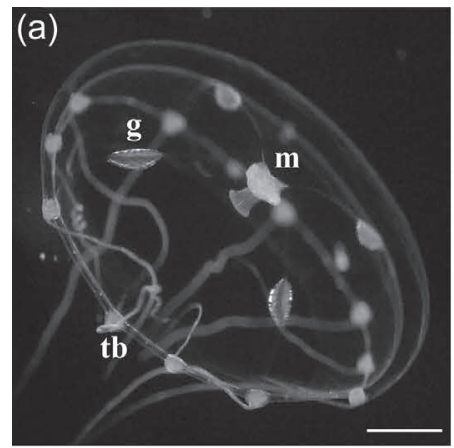

(b)

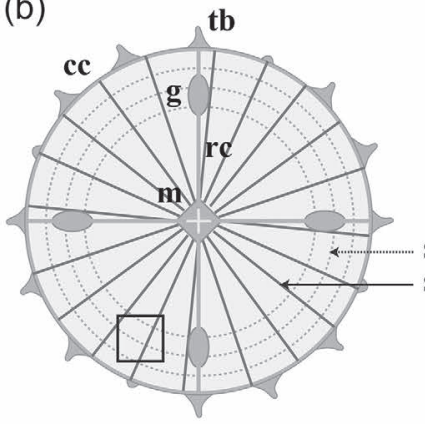

Muscle

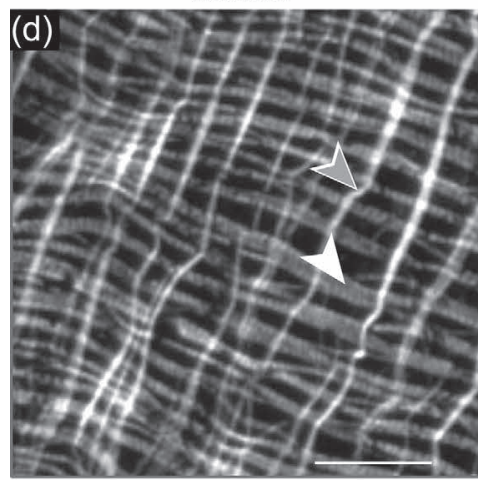

phalloidin

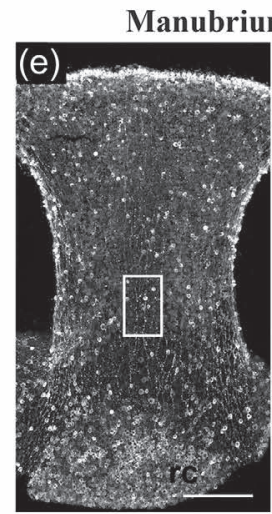

YL1/2 (nerve cells and nematocytes)

(c)
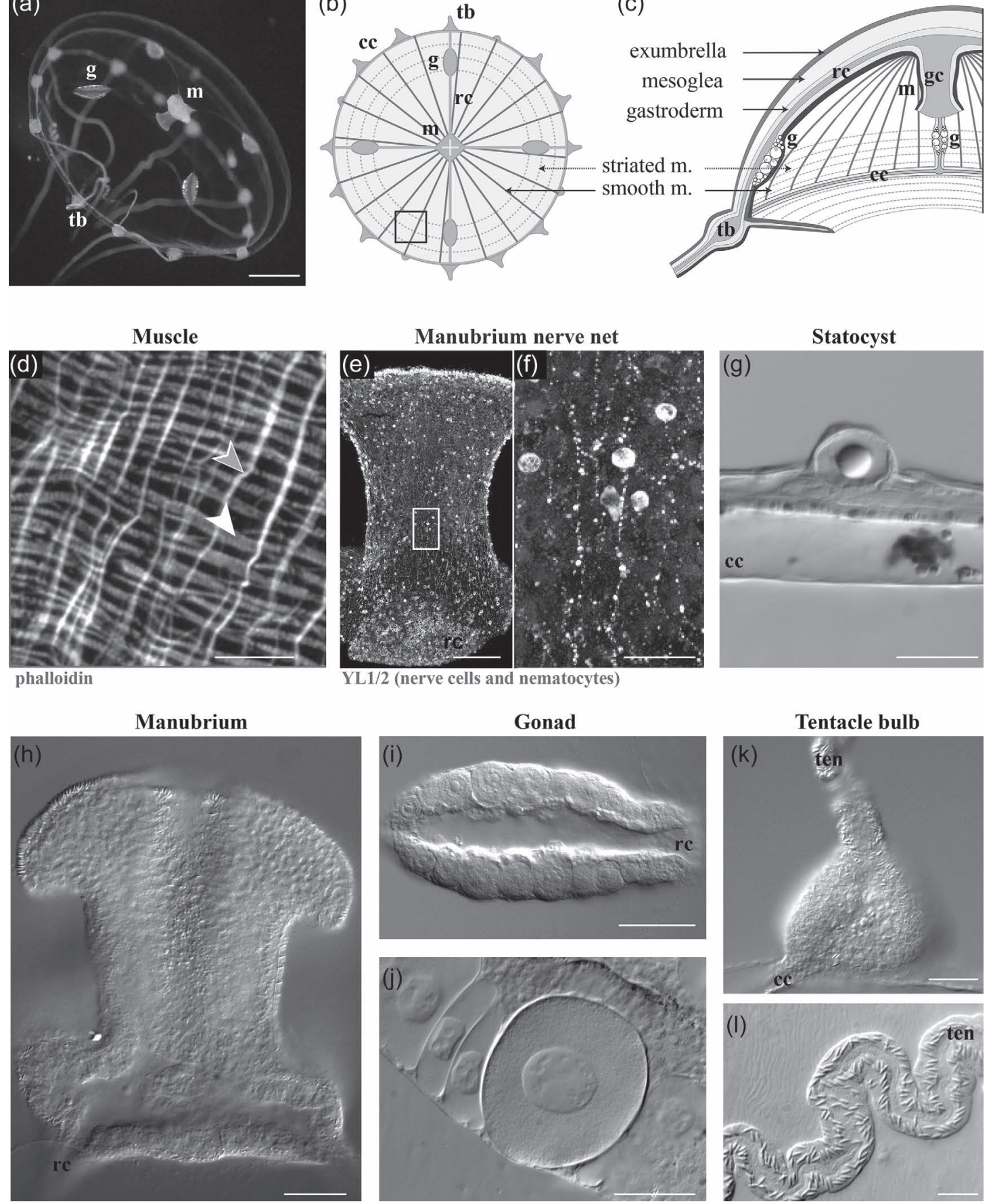

Gonad
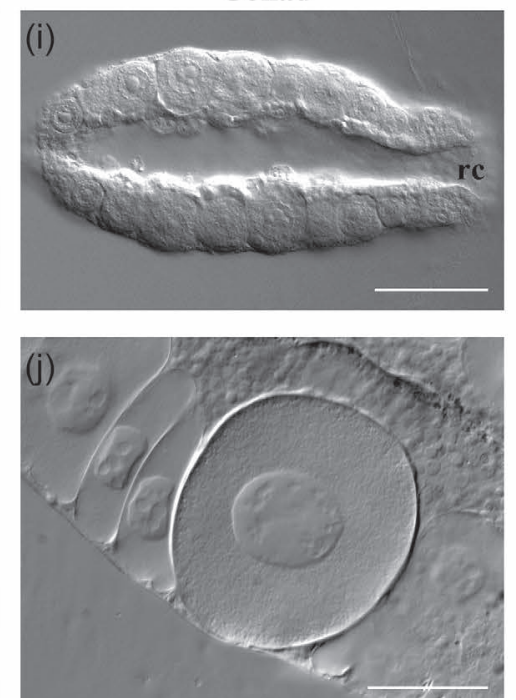

Tentacle bulb
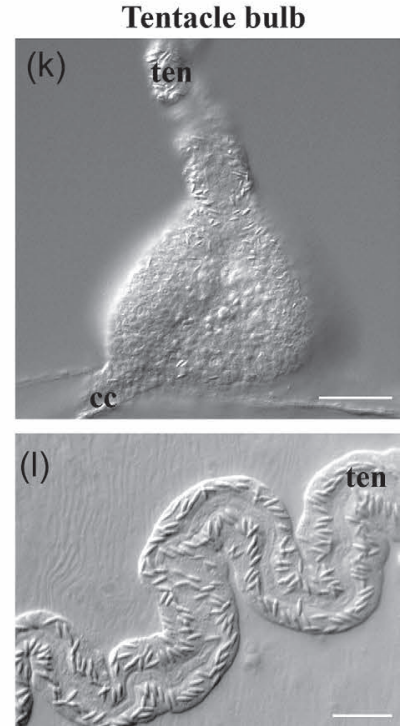

FIGURE 8.3 Morphology of Clytia jellyfish. (a) Two-week-old female jellyfish (m: manubrium, g: gonads, tb: tentacle bulbs). (b) Diagram of Clytia body organization: the jellyfish has a tetraradial symmetry organized around the centrally located tetraradial manubrium. Each quadrant contains a portion of the manubrium (m), a radial canal (rc) bearing a gonad ( $\mathrm{g}$ ) and up to eight tentacle bulbs (tb) located on the circular canal (cc). Two sets of muscle cells cause contractions of the umbrella: the radial smooth muscles (smooth m.) and the circular striated muscles (striated m.). (c) Tissue layers of the umbrella. The bell-shaped umbrella is composed of an epithelial exumbrella layer lying on the mesoglea and the subumbrella composed of an epithelial layer, the smooth muscle fibers and striated muscle fibers. (d) Confocal image of the muscles in the area marked with the square in (b). Gray and white arrowheads indicate, respectively, the smooth and striated muscle fibers stained with phalloidin. (e-f) Nervous system of the manubrium visualized by confocal microscopy, using YL1/2 antibody against tyrosinated tubulin. (g) DIC image of a statocyst located next to the circular canal (cc). (h-l) DIC pictures of the main organs of Clytia: manubrium (h) and female gonads ( $\mathrm{i}-\mathrm{j})$ linked to the radial canals $(\mathrm{rc})$, and tentacle bulbs $(\mathrm{k})$ on the circular canal (cc), with visible nematocytes capsules on the tentacle (ten) (l). Scale bars: (a) $1 \mathrm{~mm},(\mathrm{~d}, \mathrm{f}) 20 \mu \mathrm{m}$, (e) (h-k) $100 \mu \mathrm{m},(\mathrm{G}, \mathrm{L}) 50$ $\mu \mathrm{m}$. ([a-c] Adapted from Sinigaglia et al. 2020.) 
Nutrients are distributed to the umbrella through four radial canals, which run from the manubrium to the umbrella margin and are linked to the circular canal around the bell periphery. Four gonads are located on the radial canals and become visible as they start to swell during the growth of the medusa (Figure 8.3I, J). They become ready to release fully grown oocytes or sperm after two to three weeks. Proliferating cells, germline precursors deriving from the i-cells and growing oocytes are sandwiched between two epithelial layers: the gastroderm, continuous with the radial canal endoderm, and a thin epidermal covering (Amiel et al. 2010). Proliferating cells and early stages of differentiation are positioned closer to the bell, whereas the growing oocytes are located on the flanks of the gonad (Amiel and Houliston 2009; Jessus et al. 2020). Spawning is triggered by dark-light transitions.

The circular canal bears the tentacle bulbs, the structure producing nematocyte-rich tentacles (Figure 8.3K, L). After release from the gonozooid, the baby jellyfish has four primary tentacle bulbs located at the junction between the radial and circular canals. Additional bulbs are added during the growth of the umbrella, to a maximum of 32 . Nematogenesis takes place in the ectoderm of the tentacle bulbs, which is polarized (Denker et al. 2008c). I-cells expressing Nanos 1 and Piwi are located in the proximal area only, while genes for the different stages of nematogenesis (mcol3-4a, dkk, NOWA) are expressed in a staggered way along the ectoderm of the bulb. During nematogenesis, nematoblasts are thus displaced from the proximal area of the bulb to the distal area and end up in the tentacle, forming a conveyor belt (Condamine et al. 2019; Coste et al. 2016; Denker et al. 2008c).

Cnidarians are often considered to lack true organs (e.g.: Pierobon 2012). In Clytia medusae, however, manubrium, gonads and tentacle bulbs can be defined as such. Indeed, they are specialized structures performing specific functions (feeding and digestion, tentacle production, oocyte production), harboring distinct cell types (gland cells, nematocytes, germ line) and i-cell populations (manubrium: Sinigaglia et al. 2020; gonads: Leclère et al. 2012; and tentacle bulbs: Denker et al. 2008c). Moreover, these three organs are still able to perform their functions for several days after isolation from the jellyfish. Isolated gonads are able to support oocyte growth, maturation and spawning (Amiel and Houliston 2009; Quiroga Artigas et al. 2018); isolated manubria will catch and digest prey (Peron 2019); and isolated tentacle bulbs will keep producing tentacles.

\subsection{GENOMIC DATA}

\subsubsection{The Clytia hemisphaerica Genome}

The genomes of Nematostella vectensis (Putnam et al. 2007) and Hydra magnipapillata (Chapman et al. 2010) were the first cnidarian genomes to be published. Genomes from the five main cnidarians classes are now available, with the first genomes of jellyfish species published in 2019 (Gold et al. 2019; Khalturin et al. 2019; Kim et al. 2019; Leclère et al. 2019; Ohdera et al. 2019). The sequences of the different genomes showed that cnidarians possess all the main families of signaling pathways and transcription factors regulating development found in bilaterians (reviewed in: Schnitzler 2019; Technau and Schwaiger 2015).

The genome of Clytia, derived from the self-crossed lab Z strains (see Section 8.1.2), was made publicly available in 2019 (Leclère et al. 2019; http://marimba.obs-vlfr.fr/ home). It was the first published genome of a hydrozoan jellyfish. Sequencing was performed by the Genoscope using a whole-genome shotgun approach. The overall length of the published assembly was 445 megabases (Leclère et al. 2019); 26,727 genes and 69,083 transcripts were identified, which are distributed on 15 chromosome pairs. The frequency of polymorphism was relatively low $(0.9 \%)$.

Analyses of the genome highlighted gene gain and loss in the Clytia lineage. Examples of horizontal gene transfer (HGT) were identified including one of two UDP-glucose 6-dehydrogenase-like genes (Leclère et al. 2019). This enzyme is used for biosynthesis of proteoglycans and known to regulate signaling pathways during embryonic development. Some examples of gene family expansion were also identified in Clytia, such as the Innexin gap junction genes, GFP and Clytin photoprotein genes, with 39, 14 and 18 copies, respectively (Leclère et al. 2019). The analyses also revealed extensive losses of transcription factors in the hydrozoan lineage and notably several homeobox-containing transcription factors involved in nervous system development in bilaterians, as well as genes regulating the anthozoan secondary body axis.

Comparisons of transcriptomes from life cycle stages (Leclère et al. 2019) highlighted the different gene usage at planula, polyp and medusa stages. Planula stages are enriched with GPCR signaling components, polyp and medusa stages with cell-cell and cell-matrix adhesion proteins and medusa stages with a subset of transcription factors (Leclère et al. 2019). Many of the bilaterian orthologs of transcription factors specifically expressed at the medusa play important functions in neural patterning during development. Clytia-specific genes, with no identifiable ortholog in any other species, were also found to be enriched in all three stages (Leclère et al. 2019).

Together, Clytia recently published genomic and transcriptomic data revealed that: i) the genome of Clytia evolved rapidly since the divergence of hydrozoans and anthozoans, ii) this rapid evolution in the hydrozoan lineage can be linked to the evolutionary acquisition of the medusa stage and to morphological simplification of the planula and polyp and iii) the medusa stage is enriched in transcription factors conserved between bilaterians and cnidarians. Since these genes are not expressed in the planula and associated with nervous structures, they are likely involved in the establishment or maintenance of neural cell types (Leclère et al. 2019). 


\subsubsection{Transcriptomic Data}

In addition to the data included in the genome release, other transcriptomic data have been published. These focus on the gastrula stage (Lapébie et al. 2014) and tentacle bulbs (Condamine et al. 2019), as well the early stages of manubrium regeneration (Sinigaglia et al. 2020). Transcriptomes of the different tissue composing the gonad (ectoderm, endoderm, growing and fully grown oocytes) were also generated to help identify actors of oocyte maturation (Quiroga Artigas et al. 2018). About 90,000 EST and full-length sequences from cDNA libraries derived from a mix of stages (embryo, larva and medusa) are also available on NCBI dbEST (Forêt et al. 2010; Philippe et al. 2009).

\subsection{FUNCTIONAL APPROACHES: TOOLS FOR MOLECULAR AND CELLULAR ANALYSES}

Clytia is amenable for the development of tools for experimental biology at the cellular and molecular levels.

\subsubsection{Cellular Analysis}

Clytia eggs and jellyfish can be easily manipulated in a petri dish under a stereomicroscope and kept in beakers or six-well plastic plates in an incubator for further observation and manipulation. This allows pharmacological treatments for several days, as well as surgical procedures like dissections and grafts (Figure 8.4A-E) (jellyfish: Sinigaglia et al. 2020; embryos: Leclère et al. 2012; Momose and Houliston 2007). Manubriums and gonads can be easily grafted, the grafted organs connecting to the canal system of the host jellyfish (Figure 8.4A-E). The grafting approach in adult jellyfish was used to determine whether the manubrium could be a source of inductive of inhibitory signals during manubrium regeneration (Sinigaglia et al. 2020). Regeneration of the manubrium was not impaired by the grafting of an entire manubrium on the medusa subumbrella except after a graft in close proximity to the wound area, therefore excluding the hypothesis of long-range inhibition from the manubrium (Sinigaglia et al. 2020).

Embryonic stages, polyps and jellyfish are entirely transparent, making staining and imaging of different cell populations possible on fixed and living samples. Immunohistochemistry, in situ hybridization and staining using the click-it chemistry (EdU and TUNEL) are performed routinely on this species and can be combined with in situ hybridization (Figure 8.4F-H) (Sinigaglia et al. 2018). A combination of the EdU click-it staining marking proliferating cell and detection of i-cells by in situ hybridization with the probe Nanosl during regeneration of the manubrium demonstrated the displacement of Nanos $1+$ cells from the gonad to the regenerating manubrium to be followed (Sinigaglia et al. 2020).

\subsubsection{Gene Function Analysis during Embryogenesis and Oocyte Maturation}

The jellyfish used in the lab have the same genetic background, and it is easy to perform fertilizations and obtain embryo stages, facilitating gene function analyses (gain and loss of function) by injection of ARNs or MOs into the unfertilized egg (Figure 8.4I) (Momose and Houliston 2007; Momose et al. 2008). The high efficiency of loss of function by $\mathrm{MO}$ is likely due to low sequence polymorphism in the laboratory strains. Injection of mRNAs and MOs into the egg has helped us understand mechanisms involved in establishing polarity in Clytia larvae by revealing the function of maternal localized mRNAs (Wnt3, Fzl1 and Fzl3-see Section 8.4.1) (Figure 8.4J).

Clytia gonads are particularly convenient to study the molecular mechanisms underlying oogenesis. They are transparent, contain different stages of oocyte growth and continue to mature and release eggs following dark-light transition even isolated from the body of the jellyfish (Amiel et al. 2009). These characteristics were used to study the role of the Mos proteins, a conserved kinase family regulating meiosis (Amiel et al. 2009). Injection of MOs and mRNAs into the oocyte demonstrated the role of the two Clytia Mos homologs during oocyte maturation in regulating the formation and localization of the meiotic spindle, as well as oocyte cell cycle arrest after meiosis (Amiel et al. 2009). These functions have also been described in bilaterian species and likely represent an ancestral function of this protein family (Amiel et al. 2009).

\subsubsection{Gene Function Analysis in the Adult}

\subsubsection{RNA Interference}

RNA interference (RNAi) has been successfully used for downregulation of gene expression in the adult in the cnidarian Hydractinia, allowing, for instance, study of the role of i-cell genes during regeneration (Bradshaw et al. 2015). Gene expression perturbation through RNAi has not yet been performed in Clytia jellyfish; however, preliminary results indicate that the cellular machinery is present in Clytia larvae. Another promising avenue to explore is shRNA, also effective in both Hydractinia and Nematostella (DuBuc et al. 2020; He et al. 2018).

\subsubsection{The Development of Mutant Lines}

A robust protocol for achieving loss of gene function in Clytia lines by CRISPR/Cas9 has been developed (Figure 8.4K) (Momose et al. 2018). The approach was first tested on a gene involved in ciliogenesis (CheRfx123), whose defect leads to defect in sperm motility, and genes coding for the fluorescent protein GFP (Figure 8.4K) (double mutant GFPl/GFP2 in F1) (Momose et al. 2018). After injection of high doses of Cas9 RNP, mutants in the F0 generation were nearly non-mosaic and already had visible phenotypes 

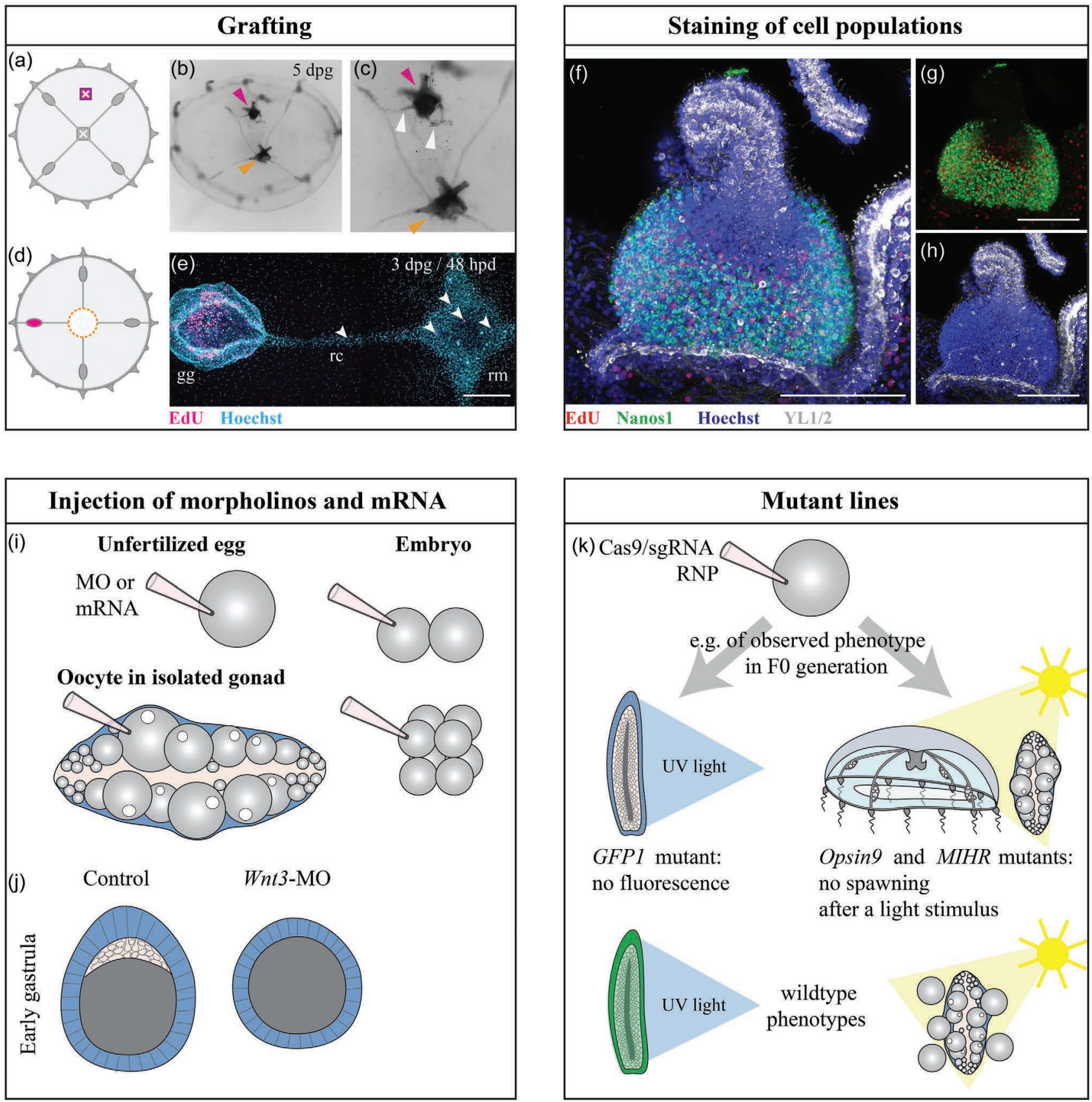

FIGURE 8.4 Tools for cellular and molecular analysis. (a-e) Organ grafting in the medusa. (a, d) Cartoons illustrating the grafting procedure: the manubrium or a gonad (both depicted in magenta) are excised from a donor medusa and placed on a host jellyfish anesthetized in menthol. After dissection, the jellyfish tissues adhere to each other. (b, c) Five days after grafting (dpg), the grafted manubrium (magenta arrowhead) has integrated the host tissue and stably coexists with the endogenous manubrium (yellow arrowhead). Both are able to catch prey and contribute to feeding; new radial canals grew from the base of the grafted manubrium (white arrowheads) and are connected to the host radial canal. (d) Donor medusa for the gonad was previously incubated in EdU, thereby marking the proliferating cells. $24 \mathrm{hpg}$, the manubrium of the host medusa was removed (dotted orange line). (e) White arrowheads indicate some EdU+ cells (magenta) from the grafted gonad (gg), which migrated into the host jellyfish through the radial canal (rc) and integrated into the regenerating manubrium (rm). (f-h) Proliferating cells (red: EdU), i-cells (green: Nanosl in situ hybridization), nerve cells and nematocytes (white: tyrosynated tubulin YL1/2 antibody staining) and nuclei (blue: Hoechst) were marked in the same tentacle bulb. (i) Perturbation of gene function through MO or ARNm injection in unfertilized oocytes, gonads or individual blastomeres of two- to eight-cell embryos. (j) Cartoons of embryos at the gastrula stage (15 hpf). Injection of Wnt3 MO before fertilization abolishes oral specification, delaying gastrulation and abolishing embryo elongation. (k) CRISPR/Cas9 mutagenesis allows gene function to be addressed at all life cycle stages. The diagrams illustrate examples of existing mutant lines and the associated phenotypes, published in Momose et al. 2018 (GFP1), Quiroga Artigas et al. 2018 (Opsin9) and 2020 (MIH-R: Maturation inducing hormone receptor). Scale bars: (e-h) $100 \mu \mathrm{m},(\mathrm{J})$ $40 \mu \mathrm{m}$. ([b, c] Adapted from Sinigaglia et al. 2020; [e] Chiara Sinigaglia.) 
(Momose et al. 2018). The relatively short Clytia life cycle allows quick generation of mutant lines. The vegetatively growing polyp colonies are essentially immortal and can be kept in the aquarium for years with minimal care (daily feeding with Artemia larvae and regular cleaning). Moreover, mutant polyp colonies can be easily split and shared between laboratories. Those characteristics make Clytia a promising genetic model. Gene insertion protocols are under development.

CRISPR/Cas9-directed mutagenesis has been used to study the molecular mechanisms of oocyte maturation and spawning triggered by light cues. It was used to knock out function of an opsin photopigment candidate for light reception (Opsin9: Quiroga Artigas et al. 2018), as well as a GPCR candidate for the oocyte maturation hormone receptor (MIHR: Quiroga Artigas et al. 2020). Lines of jellyfish carrying frame-shift mutations in the Opsin9 and MIHR genes were created by CRISPR/Cas9 (Figure 8.4K). As expected, the mutant jellyfish were unable to respond to light cues, either to trigger oocyte maturation or release gametes as in control jellyfish. Specificity was validated by reversal of Opsin mutant phenotype by treatment of oocytes with the maturation-inducing hormone or in both mutants using the downstream pathway effector cAMP (Quiroga Artigas et al. 2018, 2020).

\subsection{CHALLENGING QUESTIONS}

With the tools currently available, Clytia has the potential to address many fascinating biological questions. We illustrate this with a selection of open questions related to the extensive ability of Clytia jellyfish to regenerate and aspects of the behavior and physiology regulated by the environment.

\subsubsection{Clytia as a Regeneration Model}

Cnidarians display huge regeneration capacities, which have been well characterized in Hydra and Nematostella (Amiel et al. 2015; DuBuc et al. 2014; Galliot 2012; Schaffer et al. 2016). In contrast, cellular and molecular mechanisms of regeneration in jellyfish have been relatively unstudied. Regeneration studies in Clytia were started in the 1970s by Schmid and Tardent (see 8.1.1.3). A recent study using modern tools allowed cellular mechanisms involved in repair of the umbrella and organ regeneration to be uncovered (Sinigaglia et al. 2020). This work confirmed the potential of Clytia laboratory strains to restore their shape after amputation (Figure 8.5A, B) and to regenerate missing organs, including the manubrium (Figure $8.5 \mathrm{C}$ ). Two different mechanisms were identified (Figure 8.5D). Repair of a fragment of the umbrella, called remodeling, relies on a supracellular actomyosin cable lining the wound area and does not require cell proliferation. In contrast, morphogenesis of the regenerating manubrium requires cell proliferation, is fuelled by cell migration through the radial canals and depends on Wnt/ $\beta$-catenin signaling (Sinigaglia et al. 2020). Moreover, the regenerating manubrium is systematically associated with the point of junction of the smooth muscle fiber (called the hub), forming as a consequence of the remodeling process and expressing CheWnt6 before any visible sign of morphogenesis (Sinigaglia et al. 2020). These data suggest that local cues are involved in positioning the regenerating manubrium rather than a global patterning system. This study raises many questions about the regulation of regeneration in Clytia jellyfish.

\subsubsection{How Is the Cellular Response Controlled during Regeneration?}

Manubrium regeneration is fueled by both cell proliferation in the regeneration blastema and cell migration from distant parts of the jellyfish. At least two types of cells are mobilized: multipotent stem cells (i-cells) and differentiated digestive cells, called mobilizing gastro-digestive cells (MDG cells) (Sinigaglia et al. 2020). Cell proliferation and migration through the radial canals are necessary for regeneration of the manubrium, since regeneration is blocked at early stages in the absence of cell proliferation and if the connection to the radial canal system is interrupted (Sinigaglia et al. 2020). It is not known yet which cells are proliferating and to which extent both mechanisms of proliferation and migration contribute to the regenerating organ.

Regeneration models like planarians and the cnidarians Hydractinia require proliferation and migration of multipotent stem cells for regeneration of the anterior part (Bradshaw et al. 2015; Newmark and Sánchez Alvarado 2000). However, modes of regeneration are diverse, even within the same organism: Clytia shape restoration relies on remodeling and repatterning of existing tissues, whereas the manubrium is regenerated through cell proliferation and migration (Sinigaglia et al. 2020). Those different cell behaviors must be tightly coordinated to ensure regeneration of a correctly patterned and functional structure. Repatterning during shape restoration is controlled by tension forces generated by the actomyosin cytoskeleton. However, the mechanisms allowing fine control of cell proliferation and directing the migrating cells during organ regeneration are unknown. Elucidating the molecular control of stem cell proliferation and migration in the context of regeneration in Clytia will allow a better understanding of stem cell regulation systems in metazoans.

\subsubsection{What Are the I-Cell Fates in Clytia?}

I-cells are multipotent stem cells (see Section 8.4.2) involved in regeneration in hydrozoans (Bradshaw et al. 2015; Galliot 2013; Sinigaglia et al. 2020). The fate of i-cells has been well characterized in Hydra and Hydractinia (Gold and Jacobs 2013; Müller et al. 2004; Siebert et al. 2019). In both animals, they give rise to the gland cells, nerve cells, nematocytes and gametes. However, in Hydractinia, they also differentiate into the epithelial epidermal and gastrodermal cells; whereas in Hydra, i-cells and ectodermal and endodermal epithelial cells form three independent populations. In Clytia, only nematogenesis has been well characterized (Denker et al. 2008c). It is still unknown whether i-cells in Clytia give rise to all cell types, particularly to epithelial lineages. However, since only a small portion of Clytia 
(a)
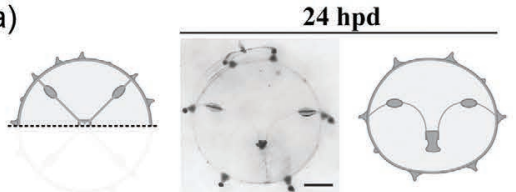

(b)

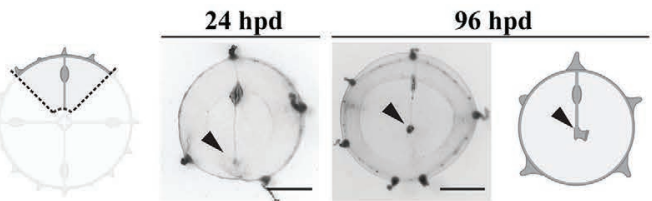

(c)

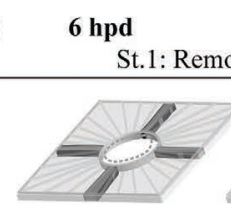

12 hpd

24 hpd St.2: Primordium
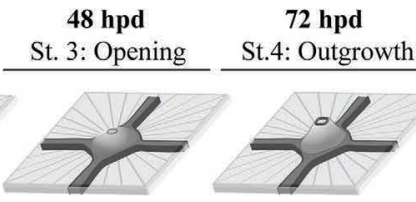

96 hpd St. 5: Folding
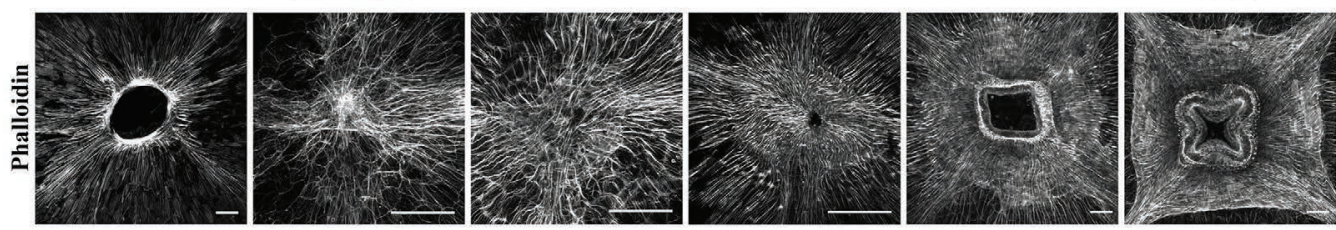

(d)

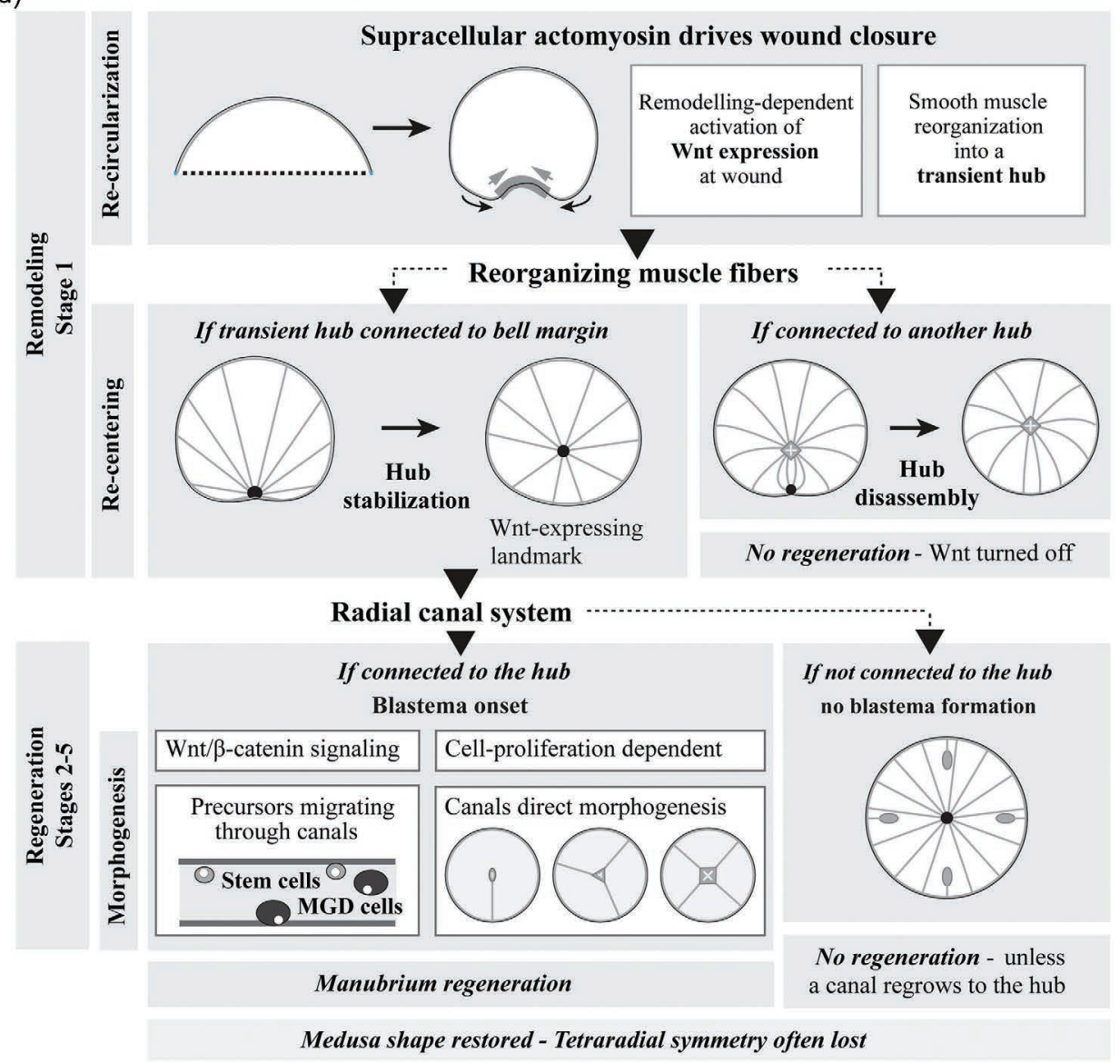

FIGURE 8.5 Regeneration of Clytia jellyfish. (a-b) Circular shape restoration after amputation. In the cartoon, the gray dashed line indicates the location of the cut. A half jellyfish with a half manubrium (a) and a quarter jellyfish without the manubrium (b) recover the circular jellyfish shape in $24 \mathrm{~h}$. In the quarter, a manubrium blastema and a tiny regenerated manubrium are visible at $24 \mathrm{hpd}$ (hours post-dissection) and 4 dpd (days post-dissection), respectively (black arrowhead). (c) Manubrium regeneration. Schematic (top line) and phalloidin staining (bottom line) of manubrium regeneration stages from 6 hpd to complete regeneration after $4 \mathrm{dpd}$. After closing of the dissection hole, a regeneration blastema forms at the junction of the radial canals. As the blastema becomes thicker, the gastric cavity opens. The regenerating manubrium first elongates, followed by the formation of four lobes. (d) Summary of the main cellular and molecular events allowing manubrium regeneration. After a cut in the umbrella, an actomyosin cable allows a rapid reestablishment of the circular jellyfish shape, affecting the organization of the smooth muscle. A new muscle hub is formed close to the former wound area. If not attached to another hub, the new hub is stabilized, as well as the associated CheWnt6 expression. The connection to the radial canal system allows the formation of a regeneration blastema by proliferation and migration of stem cells and differentiated cells, leading to the full regeneration of the missing manubrium in only four days. Scale bars: (a-b) $1 \mathrm{~mm}$, (c) $100 \mu \mathrm{m}$. ([a-d] Adapted from Sinigaglia et al. 2020.) 
proliferating cells express Nanosl, the Clytia i-cell system is likely to be similar to Hydra with separated i-cells and epithelial lineages. Transgenic lines with reporters for different cell populations allowing in vivo tracing of i-cell are necessary to identify i-cell derivatives.

It is also unknown whether all Nanos 1 -expressing cells have the same potency and particularly whether some are committed to the germline. After complete ablation, the gonads regenerate, and oocyte growth resumes. This could indicate the presence of multipotent stem cell populations in the main organs, migrating through the radial canal to repopulate the regenerating gonads. Clytia is a promising model to study early oocyte differentiation because the gonads are fully transparent and continue to function when isolated from the jellyfish.

\subsubsection{How Are Mechanical Cues and Signaling Pathways Integrated?}

After amputation, actomyosin contractility at the wound area ensures restoration of the circular jellyfish shape. During shape restoration, the signaling molecule CheWnt6 is expressed at the wound site. Its expression is inhibited by pharmacological inhibition of actomyosin contractility, suggesting a likely modulation of Wnt/ $\beta$-catenin activity by mechanical cues (Sinigaglia et al. 2020). How mechanical cues can activate Wnt/ $\beta$-catenin pathway and thus permit regeneration of the manubrium is unknown. The integration between mechanical cues and signaling pathways has been raising interest (Chiou and Collins 2018; Heisenberg and Bellaïche 2013; Urdy 2012; Vining and Mooney 2017). In Hydra, the actin cytoskeleton has also been proposed to influence body axis formation during regeneration (Livshits et al. 2017, Maroudas-Sacks et al. 2021) and is likely to be interacting with the Wnt/ $\beta$-catenin signaling pathway, inducing hypostome formation at the oral pole (Broun 2005; Gee et al. 2010).

\subsubsection{Regulation of Behavior and Physiology by Environmental Cues}

Clytia life cycle and physiology of the different life stages are influenced by the environment in many ways: i) in the ocean, settlement of the planula larva occurs upon an unknown cue from bacterial biofilms; ii) growth of the polyp colony is constrained by feeding and space availability; iii) sex of the released medusa can be influenced by the temperature at which the polyp colony is growing; and iv) in the jellyfish, oocyte maturation and gamete release are triggered by a light stimulus. Gamete release is associated with light information in many cnidarian species (e.g. scyphozoans Pelagia: Lilley et al. 2014; Clytia: Amiel et al. 2010).

\subsubsection{Which Bacterial Cues Induce Settlement of the Planula? Which Molecular Mechanisms Are Triggered?}

In cnidarians, including Clytia, settlement of the planula larva and metamorphosis into a primary polyp is induced by bacterial biofilms (Hydractinia echinata: Kroiher and Berking 1999; Leitz and Wagner 1993; Seipp et al. 2007; Acropora sp: Negri et al. 2001; Tebben et al. 2011; Webster et al. 2004). The cellular response is mediated by neuropeptides of the GLW-amide family, secreted by sensory neurons of the planula (Takahashi and Takeda 2015). Synthetic GLW-amide neuropeptides induce settlement and metamorphosis in laboratory conditions in several planulae (Acropora: Iwao et al. 2002; Hydractinia: Müller and Leitz 2002; both reviewed in: Takahashi and Hatta 2011). Concerning Clytia planula, the synthetic peptide GLWamide2 (GNPPGLW-NH2) has been used in the laboratory to induce settlement (Momose et al. 2018; Quiroga Artigas et al. 2018). A recent study testing the efficiency of 15 other neuropeptides, derived from sequences of potential GLWamide precursors, showed that GLWamide-6 (pyroGlu-QQAPKGLW-NH3) has an even greater efficiency (Lechable et al. 2020).

The roles of bacteria and neuropeptides in settlement have long been known. However, the signal from the bacteria inducing settlement and metamorphosis, as well as the molecular mechanisms triggering settlement and metamorphosis, are still unknown. The morphological and cellular events occurring during the metamorphosis of Clytia planula have been recently studied (Krasovec 2020) and provide a framework for further studies on metamorphosis.

\subsubsection{Is There a Physiological Link between Gametogenesis and Nutrition?}

In Clytia jellyfish, spawning and oocyte maturation occurs in males and females two hours after a light stimulus (Amiel et al. 2010). Part of the signaling cascade triggering lightinduced oocyte maturation has recently been elucidated. After light reception by the photoprotein Opsin9 by neurosecretory cells of the gonad ectoderm, those cells release a maturation-inducing hormone (Quiroga Artigas et al. 2018). MIH activates in turn a GPCR, located on the oocyte surface, called the MIH-Receptor, thus triggering the rise in cAMP responsible for the initiation of oocyte maturation (Quiroga Artigas et al. 2020). Besides their function in oocyte maturation, Clytia MIH and MIH-R are likely to play a role in nutrition or other physiological processes. Indeed, both are expressed in the gastrovascular system and the tentacles as well as in the gonads. Moreover, MIHR is part of a superfamily of cnidarian and bilaterian GPCRs playing a role in nutrition, as well as regulation of sexual reproduction (Quiroga Artigas et al. 2020). Additional knowledge in the functions of Clytia MIHR could give insight in the evolution of the link between gametogenesis and nutrition.

\subsubsection{How Does Feeding Availability Regulate Growth of Polyps and Medusa?}

Some cnidarians are able to modify their size depending on feeding availability. The jellyfish Pelagia noctiluca and Aurelia aurita shrink during starvation conditions and regrow when prey are again available (Frandsen and Riisgård 1997; Hamner and Jenssen 1974; Lilley et al. 2014). In 
laboratory conditions, Aurelia aurita loses 3-5\% of its mass per day without feeding and regrows after feeding to reach the original size. Starved jellyfish are not able to spawn (Frandsen and Riisgård 1997; Hamner and Jenssen 1974). Similarly to Aurelia, Pelagia loses about $7 \%$ of its mass per day and can regrow after feeding. However, egg production is maintained, with a number of eggs correlated with the size of the jellyfish (Lilley et al. 2014).

The process of shrinking in conditions of starvation is also a feature of other invertebrates. In planarians, the size depends on the feeding levels (Felix et al. 2019); in the annelid Pristina leidyi, feeding causes the increase and decrease of the gonads (Özpolat et al. 2016). This process has also been documented, although more rarely, in the vertebrates. The marine iguana Amblyrhynchus cristatus can lose up to $20 \%$ of its size after the loss of its main source of food during El Niño events (Wikelski and Thom 2000). Whether the same mechanisms are involved between metazoans still remains to be investigated.

A similar shrinking/re-growth event in case of starvation has been observed in Clytia jellyfish (unpublished). Moreover, the gonads also shrink and egg production declines before totally stopping. Gametogenesis resumes after feeding of the jellyfish. The recently described MDG cells, with a putative role in the distribution of nutrients, circulate more in the canals in case of starvation (Sinigaglia et al. 2020). Feeding also influences the growth of newly released jellyfish: indeed, jellyfish fed with smaller prey, and thus with a bigger food intake, grow faster than jellyfish fed with bigger prey that are harder to catch (Lechable et al. 2020).

To summarize, in Clytia, like in other cnidarians, the feeding levels control the rate of growth and gametogenesis. The cellular and molecular mechanisms allowing the control of growth in Clytia jellyfish are unknown. One level of regulation is potentially the cell cycle, since in Hydra and Nematostella polyps, the rate of cell proliferation depends on the feeding level of the animal (Campbell 1967; Otto and Campbell 1977; Passamaneck and Martindale 2012; Webster and Hamilton 1972). Clytia jellyfish could be used to investigate the feedback between feeding levels and cell proliferation, as well as cellular events during degrowth.

Many fascinating questions can be addressed with Clytia. Due to its practicality as a model organism and the tools already available and in development, Clytia has the potential to provide a fresh perspective on a wide range of research topics.

\section{BIBLIOGRAPHY}

Abrams, M.J., T. Basinger, W. Yuan, C.-L. Guo, and L. Goentoro. 2015. Self-repairing symmetry in jellyfish through mechanically driven reorganization. Proceedings of the National Academy of Sciences. 112: E3365-E3373.

Alder, J. 1856. A notice of some new genera and species of British hydroid zoophytes. Annals and Magazine of Natural History. 2: 12-14.

Amiel, A., P. Chang, T. Momose, and E. Houliston. 2010. Clytia hemisphaerica: A cnidarian model for studying oogenesis. In
Oogenesis, ed. M.-H. Verlhac \& A. Villeneuve, 81-101. John Wiley \& Sons.

Amiel, A., and E. Houliston. 2009. Three distinct RNA localization mechanisms contribute to oocyte polarity establishment in the cnidarian Clytia hemispharica. Developmental Biology. 327: 191-203.

Amiel, A.R., H.T. Johnston, K. Nedoncelle, J.F. Warner, S. Ferreira, and E. Röttinger. 2015. Characterization of morphological and cellular events underlying oral regeneration in the sea anemone, Nematostella vectensis. International Journal of Molecular Sciences. 16: 28449-28471.

Amiel, A., L. Leclère, L. Robert, S. Chevalier, and E. Houliston. 2009. Conserved functions for Mos in eumetazoan oocyte maturation revealed by studies in a cnidarian. Current Biology. 19: 305-311.

Bodo, F., and J. Bouillon. 1968. Etude histologique du développement embryonnaire de quelques hydromeduses de Roscoff: Phialidium hemisphaericum (1.), Obelia sp. peron et lesueur, Sarsia eximia (allman), Podocoryne carnea (sars), Gonionemus vertens Agassiz. Cahiers de Biologie Marine. 9: 69-104.

Bode, H.R. 1996. The interstitial cell lineage of Hydra: A stem cell system that arose early in evolution. Journal of Cell Science. 109: 1155-1164.

Bode, H.R., S. Heimfeld, M.A. Chow, and L.W. Huang. 1987. Gland cells arise by differentiation from interstitial cells in Hydra attenuata. Developmental Biology. 122: 577-585.

Bosch, T.C.G., F. Anton-Erxleben, G. Hemmrich, and K. Khalturin. 2010. The Hydra polyp: Nothing but an active stem cell community. Development Growth and Differentiation. 52: $15-25$.

Bosch, T.C.G., and C.N. David. 1987. Stem cells of Hydra magnipapillata can differentiate into somatic cells and germ line cells. Developmental Biology. 121: 182-191.

Bradshaw, B., K. Thompson, and U. Frank. 2015. Distinct mechanisms underlie oral vs aboral regeneration in the cnidarian Hydractinia echinata. ELife. 4: 1-19.

Broun, M. 2005. Formation of the head organizer in hydra involves the canonical Wnt pathway. Development. 132: 2907-2916.

Brusca, R.C., W. Moore, and S.M. Shuster. 2016. Invertebrates. 3rd ed. Sinauer Associates Inc., Sunderland, MA.

Byrum, C.A. 2001. An analysis of hydrozoan gastrulation by unipolar ingression. Developmental Biology. 240: 627-640.

Campbell, R.D. 1967. Tissue dynamics of steady state growth in Hydra littoralis. I: Patterns of cell division. Developmental Biology. 15: 487-502.

Carré, D., and C. Carré. 2000. Origin of germ cells, sex determination, and sex inversion in medusae of the genus Clytia (Hydrozoa, Leptomedusae): The influence of temperature. Journal of Experimental Zoology. 287: 233-242.

Carré, D., C. Carré, F. Pagès, and J.-M. Gili. 1995. Asexual reproduction in the pelagic phase of Clytia mccrady (Hydrozoa, Leptomedusae). Scientia Marina. 59: 193-202.

Chapman, D.M. 1985. X-ray microanalysis of selected coelenterate statoliths. Journal of the Marine Biological Association of the United Kingdom. 65: 617-627.

Chapman, J.A., E.F. Kirkness, O. Simakov, S.E. Hampson, T. Mitros, T. Weinmaier, T. Rattei, P.G. Balasubramanian, J. Borman, D. Busam, K. Disbennett, C. Pfannkoch, N. Sumin, G.G. Sutton, L.D. Viswanathan, B. Walenz, D.M. Goodstein, U. Hellsten, T. Kawashima, et al. 2010. The dynamic genome of Hydra. Nature. 464: 592-596.

Chevalier, S., A. Martin, L. Leclère, A. Amiel, and E. Houliston. 2006. Polarised expression of FoxB and FoxQ2 genes 
during development of the hydrozoan Clytia hemisphaerica. Development Genes and Evolution. 216: 709-720.

Chiori, R., M. Jager, E. Denker, P. Wincker, C. Da Silva, H. Le Guyader, M. Manuel, and E. Quéinnec. 2009. Are Hox genes ancestrally involved in axial patterning? evidence from the hydrozoan Clytia hemisphaerica (Cnidaria). PLoS One. 4: e4231.

Chiou, K., and E.M.S. Collins. 2018. Why we need mechanics to understand animal regeneration. Developmental Biology. 433: $155-165$.

Collins, A., P. Schuchert, A. Marques, T. Jankowski, M. Medina, and B. Schierwater. 2006. Medusozoan phylogeny and character evolution clarified by new large and small subunit RDNA data and an assessment of the utility of phylogenetic mixture models. Systematic Biology. 55: 97-115.

Condamine, T., M. Jager, L. Leclère, C. Blugeon, S. Lemoine, R.R. Copley, and M. Manuel. 2019. Molecular characterisation of a cellular conveyor belt in Clytia medusae. Developmental Biology. 456: 212-225.

Coste, A., M. Jager, J.P. Chambon, and M. Manuel. 2016. Comparative study of Hippo pathway genes in cellular conveyor belts of a ctenophore and a cnidarian. EvoDevo. 7: 1-19.

Cunha, A.F., A.G. Collins, and A.C. Marques. 2020. When morphometry meets taxonomy: Morphological variation and species boundaries in Proboscoida (Cnidaria: Hydrozoa). Zoological Journal of the Linnean Society. 190: 417-447.

Davis, L.E. 1974. Ultrastructural studies of the development of nerves in Hydra. Integrative and Comparative Biology. 14: 551-573.

Denker, E., E. Bapteste, H. Le Guyader, M. Manuel, and N. Rabet. 2008a. Horizontal gene transfer and the evolution of cnidarian stinging cells. Current Biology. 18: 858-859.

Denker, E., A. Chatonnet, and N. Rabet. 2008b. Acetylcholinesterase activity in Clytia hemisphaerica (Cnidaria). ChemicoBiological Interactions. 175: 125-128.

Denker, E., M. Manuel, L. Leclère, H. Le Guyader, and N. Rabet. 2008c. Ordered progression of nematogenesis from stem cells through differentiation stages in the tentacle bulb of Clytia hemisphaerica (Hydrozoa, Cnidaria). Developmental Biology. 315: 99-113.

Derelle, R., T. Momose, M. Manuel, C.D.A. Silva, P. Wincker, and E. Houliston. 2010. Convergent origins and rapid evolution of spliced leader trans-splicing in Metazoa: Insights from the Ctenophora and Hydrozoa. RNA. 16: 696-707.

DuBuc, T.Q., C.E. Schnitzler, E. Chrysostomou, E.T. McMahon, Febrimarsa, J.M. Gahan, T. Buggie, S.G. Gornik, S. Hanley, S.N. Barreira, P. Gonzalez, A.D. Baxevanis, and U. Frank. 2020. Transcription factor AP2 controls cnidarian germ cell induction. Science. 367: 757-762.

DuBuc, T.Q., N. Traylor-Knowles, and M.Q. Martindale. 2014. Initiating a regenerative response: Cellular and molecular features of wound healing in the cnidarian Nematostella vectensis. BMC Biology. 12: 1-20.

Felix, D.A., Ó. Gutiérrez-Gutiérrez, L. Espada, A. Thems, and C. González-Estévez. 2019. It is not all about regeneration: Planarians striking power to stand starvation. Seminars in Cell and Developmental Biology. 87: 169-181.

Forêt, S., B. Knack, E. Houliston, T. Momose, M. Manuel, E. Quéinnec, D.C. Hayward, E.E. Ball, and D.J. Miller. 2010. New tricks with old genes: The genetic bases of novel cnidarian traits. Trends in Genetics. 26: 154-158.

Fourrage, C., S. Chevalier, and E. Houliston. 2010. A highly conserved poc1 protein characterized in embryos of the hydrozoan Clytia hemisphaerica: Localization and functional studies. PLoS One. 5: e13994.
Frandsen, K.T., and H.U. Riisgård. 1997. Size dependent respiration and growth of jellyfish, Aurelia aurita. Sarsia. 82: 307-312.

Freeman, G. 1980. The role of cleavage in the establishment of the anterior-posterior axis of the hydrozoan embryo. In Developmental and Cellular Biology of Coelenterates, ed. R. Tardent \& P. Tardent, 97-108. Elsevier/North Holland. Amsterdam.

Freeman, G. 1981a. The role of polarity in the development of the hydrozoan planula larva. Wilhelm Roux's Archives of Developmental Biology. 190: 168-184.

Freeman, G. 1981b. The cleavage initiation site establishes the posterior pole of the hydrozoan embryo. Wilhelm Roux's Archives of Developmental Biology. 190: 123-125.

Freeman, G. 2005. The effect of larval age on developmental changes in the polyp prepattern of a hydrozoan planula. Zoology. 108: 55-73.

Freeman, G., and E.B. Ridgway. 1987. Endogenous photoproteins, calcium channels and calcium transients during metamorphosis in hydrozoans. Roux's Archives of Developmental Biology. 196: 30-50.

Galliot, B. 2012. Hydra, a fruitful model system for 270 years. International Journal of Developmental Biology. 56: 411-423.

Galliot, B. 2013. Regeneration in Hydra. In ELS, John Wiley \& Sons. Chichester.

Gee, L., J. Hartig, L. Law, J. Wittlieb, K. Khalturin, T.C.G. Bosch, and H.R. Bode. 2010. $\beta$-Catenin plays a central role in setting up the head organizer in Hydra. Developmental Biology. 340: 116-124.

Gold, D.A., and D.K. Jacobs. 2013. Stem cell dynamics in cnidaria: Are there unifying principles? Development Genes and Evolution. 223: 53-66.

Gold, D.A., T. Katsuki, Y. Li, X. Yan, M. Regulski, D. Ibberson, T. Holstein, R.E. Steele, D.K. Jacobs, and R.J. Greenspan. 2019. The genome of the jellyfish Aurelia and the evolution of animal complexity. Nature Ecology \& Evolution. 3: 96-104.

Gur Barzilai, M., A.M. Reitzel, J.E.M. Kraus, D. Gordon, U. Technau, M. Gurevitz, and Y. Moran. 2012. Convergent evolution of sodium ion selectivity in metazoan neuronal signaling. Cell Reports. 2: 242-248.

Hale, L.J. 1973. The pattern of growth of Clytia johnstoni. Journal of Embryology and Experimental Morphology. 29: 283-309.

Hamner, W.M., and R.M. Jenssen. 1974. Growth, degrowth, and irreversible cell differentiation in Aurelia aurita. American Zoologist. 14: 833-849.

Hargitt, C.W. 1897. Recent experiments on regeneration. Zoological Bulletin. 1: 27.

He, S., F. Del Viso, C.Y. Chen, A. Ikmi, A.E. Kroesen, and M.C. Gibson. 2018. An axial Hox code controls tissue segmentation and body patterning in Nematostella vectensis. Science. 361: 1377-1380.

Heisenberg, C.P., and Y. Bellaïche. 2013. Forces in tissue morphogenesis and patterning. Cell. 153: 948.

Houliston, E., T. Momose, and M. Manuel. 2010. Clytia hemisphaerica: A jellyfish cousin joins the laboratory. Trends in Genetics. 26: 159-167.

Iwao, K., T. Fujisawa, and M. Hatta. 2002. A cnidarian neuropeptide of the glwamide family induces metamorphosis of reef-building corals in the genus Acropora. Coral Reefs. 21: 127-129.

Jessus, C., C. Munro, and E. Houliston. 2020. Managing the oocyte meiotic arrest-Lessons from frogs and jellyfish. Cells. 9: 1150-1185. 
Kamran, Z., K. Zellner, H. Kyriazes, C.M. Kraus, J.B. Reynier, and J.E. Malamy. 2017. In vivo imaging of epithelial wound healing in the cnidarian Clytia hemisphaerica demonstrates early evolution of purse string and cell crawling closure mechanisms. BMC Developmental Biology. 17: 1-14.

Khalturin, K., C. Shinzato, M. Khalturina, M. Hamada, M. Fujie, R. Koyanagi, M. Kanda, H. Goto, F. Anton-Erxleben, M. Toyokawa, S. Toshino, and N. Satoh. 2019. Medusozoan genomes inform the evolution of the jellyfish body plan. Nature Ecology and Evolution. 3: 811-822.

Kim, H.M., J.A. Weber, N. Lee, S.G. Park, Y.S. Cho, Y. Bhak, N. Lee, Y. Jeon, S. Jeon, V. Luria, A. Karger, M.W. Kirschner, Y.J. Jo, S. Woo, K. Shin, O. Chung, J.C. Ryu, H.S. Yim, J.H. Lee, J.S. Edwards, A. Manica, J. Bhak, and S. Yum. 2019. The genome of the giant nomura's jellyfish sheds light on the early evolution of active predation. BMC Biology. 17: 1-12.

Krasovec, G. 2020. Compréhension du role morphogenetique de l'apoptose et de son évolution: apports de l'etude de la metamorphose de Ciona Intestinalis (Tunicata) et de Clytia hemisphaerica (Cnidaria). $\mathrm{PhD}$ thesis. Sorbonne Université, Paris.

Kraus, J.E., D. Fredman, W. Wang, K. Khalturin, and U. Technau. 2015. Adoption of conserved developmental genes in development and origin of the medusa body plan. EvoDevo. 6.

Kraus, Y., S. Chevalier, and E. Houliston. 2020. Cell shape changes during larval body plan development in Clytia hemisphaerica. Developmental Biology. 468: 59-79.

Kroiher, M., and S. Berking. 1999. On natural metamorphosis inducers of the cnidarians Hydractinia echinata (Hydrozoa) and Aurelia aurita (Scyphozoa). Helgoland Marine Research. 53: 118-121.

Kubota, S. 1978. The life-history of Clytia edwardsi (Hydrozoa; Campanulariidae) in Hokkaido, Japan. Jour. Fac. Sci. Hokkaido Univ. Ser. VI, Zool. 21: 317-354.

Lacassagne M. 1961. Histologie comparée des planulas de quelques Hydraires. Diplome d'études supérieures. Paris.

Lapébie, P., A. Ruggiero, C. Barreau, S. Chevalier, P. Chang, P. Dru, E. Houliston, and T. Momose. 2014. Differential responses to Wnt and PCP disruption predict expression and developmental function of conserved and novel genes in a cnidarian. PLoS Genetics. 10: e1004590.

Lechable, M., A. Jan, A. Duchene, J. Uveira, B. Weissbourd, L. Gissat, S. Collet, L. Gilletta, S. Chevalier, L. Leclère, S. Peron, C. Barreau, R. Lasbleiz, E. Houliston, and T. Momose. 2020. An improved whole life cycle culture protocol for the hydrozoan genetic model Clytia hemisphaerica. Biology Open: bio.051268.

Leclère, L. 2008. Evolution de la reproduction sexuee des hydrozoaires: aspects historiques, analyse phylogenetique et developpementale. $\mathrm{PhD}$ thesis. Université Pierre et Marie Curie, Paris.

Leclère, L., R.R. Copley, T. Momose, and E. Houliston. 2016. Hydrozoan insights in animal development and evolution. Current Opinion in Genetics and Development. 39: 157-167.

Leclère, L., C. Horin, S. Chevalier, P. Lapébie, P. Dru, S. Peron, M. Jager, T. Condamine, K. Pottin, S. Romano, J. Steger, C. Sinigaglia, C. Barreau, G. Quiroga Artigas, A. Ruggiero, C. Fourrage, J.E.M. Kraus, J. Poulain, J.M. Aury, P. Wincker, E. Quéinnec, U. Technau, M. Manuel, T. Momose, E. Houliston, and R.R. Copley. 2019. The genome of the jellyfish Clytia hemisphaerica and the evolution of the cnidarian life-cycle. Nature Ecology and Evolution. 3: 801-810.

Leclère, L., M. Jager, C. Barreau, P. Chang, H. Le Guyader, M. Manuel, and E. Houliston. 2012. Maternally localized germ plasm mRNAs and germ cell/stem cell formation in the cnidarian Clytia. Developmental Biology. 364: 236-248.

Leitz, T., and T. Wagner. 1993. The marine bacterium Alteromonas espejiana induces metamorphosis of the hydroid Hydractinia Echinata. Marine Biology. 115: 173-178.

Lilley, M.K.S., A. Elineau, M. Ferraris, A. Thiéry, L. Stemmann, G. Gorsky, and F. Lombard. 2014. Individual shrinking to enhance population survival: Quantifying the reproductive and metabolic expenditures of a starving jellyfish, Pelagia noctiluca. Journal of Plankton Research. 36: 1585-1597.

Linnaeus, C. 1767. Systema naturae per regna tria naturae: Secundum classes, ordines, genera, species, cum characteribus, differentiis, synonymis, locis. Laurentii Salvii. Stockholm.

Livshits, A., L. Shani-Zerbib, Y. Maroudas-Sacks, E. Braun, and K. Keren. 2017. Structural inheritance of the actin cytoskeletal organization determines the body axis in regenerating Hydra. Cell Reports. 18: 1410-1421.

Lucas, C.H., D.W. Williams, J.A. Wiliams, and M. Sheader. 1995. Seasonal dynamics and production of the hydromedusan Clytia hemisphaerica (Hydromedusa: Leptomedusa) in Southampton water. Estuaries. 18: 362-372.

Malamy, J.E., and M. Shribak. 2018. An orientation-independent DIC microscope allows high resolution imaging of epithelial cell migration and wound healing in a cnidarian model. Journal of Microscopy. 270: 290-301.

Maroudas-Sacks Y., L. Garion, L. Shani-Zerbib, A. Livshits, E. Braun, and K. Keren. 2021. Topological defects in the nematic order of actin fibres as organization centres of Hydra morphogenesis. Nature Physics. 17: 251-259.

Metchnikoff, E. 1886. Embryologische Studien an Medusen: Ein Beitrag Zur Genealogie Der Primitiv-Organe. Alfred Hölder. Wien.

Mills, C.E. 1983. Vertical migration and diel activity patterns of hydromedusae: Studies in a large tank. Journal of Plankton Research. 5: 619-635.

Momose, T., A. De Cian, K. Shiba, K. Inaba, C. Giovannangeli, and J.P. Concordet. 2018. High doses of CRISPR/Cas9 ribonucleoprotein efficiently induce gene knockout with low mosaicism in the hydrozoan Clytia hemisphaerica through microhomology-mediated deletion. Scientific Reports. 8: $5-10$.

Momose, T., R. Derelle, and E. Houliston. 2008. A maternally localised Wnt ligand required for axial patterning in the cnidarian Clytia hemisphaerica. Development. 135: 2105-2113.

Momose, T., and E. Houliston. 2007. Two oppositely localised Frizzled RNAs as axis determinants in a cnidarian embryo. PLoS Biology. 5: 889-899.

Momose, T., Y. Kraus, and E. Houliston. 2012. A conserved function for Strabismus in establishing planar cell polarity in the ciliated ectoderm during cnidarian larval development. Development. 139: 4374-4382.

Morgan, T.H. 1899. Regeneration in the Hydromedusa, Gonionemus vertens. The American Naturalist. 33: 939-951.

Müller, W.A., and T. Leitz. 2002. Metamorphosis in the Cnidaria. Canadian Journal of Zoology. 80: 1755-1771.

Müller, W.A., R. Teo, and U. Frank. 2004. Totipotent migratory stem cells in a hydroid. Developmental Biology. 275: 215-224.

Negri, A.P., N.S. Webster, R.T. Hill, and A.J. Heyward. 2001. Metamorphosis of broadcast spawning corals in response to bacteria isolated from crustose algae. Marine Ecology Progress Series. 223: 121-131.

Neppi, V. 1918. Sulla rigenerazione nelle idromeduse. Pubblicazioni Della Stazione Zoologica Di Napoli. 2: 191-207. 
Newmark, P.A., and A. Sánchez Alvarado. 2000. Bromodeoxyuridine specifically labels the regenerative stem cells of planarians. Developmental Biology. 220: 142-153.

Nishimiya-Fujisawa, C., and S. Kobayashi. 2012. Germline stem cells and sex determination in Hydra. International Journal of Developmental Biology. 56: 499-508.

Ohdera, A., C.L. Ames, R.B. Dikow, E. Kayal, M. Chiodin, B. Busby, S. La, S. Pirro, A.G. Collins, M. Medina, and J.F. Ryan. 2019. Box, stalked, and upside-down? Draft genomes from diverse jellyfish (Cnidaria, Acraspeda) lineages: Alatina alata (Cubozoa), Calvadosia cruxmelitensis (Staurozoa), and Cassiopea xamachana (Scyphozoa). GigaScience. 8: 1-15.

Okada, Y.K. 1927. Etudes sur la regeneration chez les coelentérés. Archives de Zoologie Expérimentale et Générale: Histoire Naturelle. 66: 497-551.

Otto, J.J., and R.D. Campbell. 1977. Tissue economics of Hydra: Regulation of cell cycle, animal size and development by controlled feeding rates. Journal of Cell Science. 28: 117-132.

Özpolat, B.D., E.S. Sloane, E.E. Zattara, and A.E. Bely. 2016. Plasticity and regeneration of gonads in the annelid Pristina leidyi. EvoDevo. 7: 22.

Passamaneck, Y.J., and M.Q. Martindale. 2012. Cell proliferation is necessary for the regeneration of oral structures in the anthozoan cnidarian Nematostella vectensis. BMC Developmental Biology. 12: 34.

Peron, S. 2019. Bases cellulaires et moleculaires de la regeneration chez la meduse Clytia hemisphaerica. $\mathrm{PhD}$ thesis. Sorbonne université, Paris.

Philippe, H., R. Derelle, P. Lopez, K. Pick, C. Borchiellini, N. Boury-Esnault, J. Vacelet, E. Renard, E. Houliston, E. Quéinnec, C. Da Silva, P. Wincker, H. Le Guyader, S. Leys, D.J. Jackson, F. Schreiber, D. Erpenbeck, B. Morgenstern, G. Wörheide and M. Manuel. 2009. Phylogenomics revives traditional views on deep animal relationships. Current Biology. 19: 706-712.

Pierobon, P. 2012. Coordinated modulation of cellular signaling through ligand-gated ion channels in Hydra vulgaris (Cnidaria, Hydrozoa). International Journal of Developmental Biology. 56: 551-565.

Piraino, S., G. Zega, C. Di Benedetto, A. Leone, A. Dell'Anna, R. Pennati, D. Candia Carnevali, V. Schmid, and H. Reichert. 2011. Complex neural architecture in the diploblastic larva of Clava multicornis (Hydrozoa, Cnidaria). Journal of Comparative Neurology. 519: 1931-1951.

Putnam, N.H., M. Srivastava, U. Hellsten, B. Dirks, J. Chapman, A. Salamov, A. Terry, H. Shapiro, E. Lindquist, V. Vladimir, J. Jurka, G. Genikhovich, I. Grigoriev, J.G.I. Sequencing, R.E. Steele, J. Finnerty, U. Technau, M.Q. Martindale, and D.S. Rokhsar. 2007. Sea anemone genome reveals the gene repertoire and genomic organization of the eumetazoan ancestor. Science. 317: 86-94.

Quiquand, M., N. Yanze, J. Schmich, V. Schmid, B. Galliot, and S. Piraino. 2009. More constraint on ParaHox than Hox gene families in early metazoan evolution. Developmental Biology. 328: 173-187.

Quiroga Artigas, G. 2017. Light-induced oocyte maturation in the hydrozoan Clytia hemisphaerica. PhD thesis. Université Pierre et Marie Curie, Paris.

Quiroga Artigas, G., P. Lapébie, L. Leclère, P. Bauknecht, J. Uveira, S. Chevalier, G. Jékely, T. Momose, and E. Houliston. 2020. A G protein-coupled receptor mediates neuropeptide-induced oocyte maturation in the jellyfish Clytia. PLoS Biology. 18: $1-38$.

Quiroga Artigas, G., P. Lapébie, L. Leclère, N. Takeda, R. Deguchi, G. Jékely, T. Momose, and E. Houliston. 2018. A gonad-expressed opsin mediates light-induced spawning in the jellyfish Clytia. ELife. 7: 1-22.

Roosen-Runge, E. 1962. On the biology of sexual reproduction of hydromedusae, genus Phialidium Leuckhart. Pacific Science. 16: $15-31$.

Ruggiero, A. 2015. Impact of Wnt signalling on multipotent stem cell dynamics during Clytia hemisphaerica embryonic and larval development. PhD thesis. Université Pierre et Marie Curie, Paris.

Satterlie, R.A. 2002. Neuronal control of swimming in jellyfish: A comparative story. Canadian Journal of Zoology. 80: 1654-1669.

Schaffer, A.A., M. Bazarsky, K. Levy, V. Chalifa-Caspi, and U. Gat. 2016. A transcriptional time-course analysis of oral vs. aboral whole-body regeneration in the sea anemone Nematostella vectensis. BMC Genomics. 17: 718.

Schmid, B., V. Schmid, and P. Tardent. 1974. The umbrellar growth process in the Leptomedusae Phialidium hemisphaericum (Syn. Campanularia johnstoni). Experienti 30: 1399-1400.

Schmid, V. 1974. Regeneration in medusa buds and medusae of Hydrozoa. American Zoologist. 14: 773-781.

Schmid, V., and P. Tardent. 1971. The reconstitutional performances of the Leptomedusa Campanularia jonstoni. Marine Biology. 8: 99-104.

Schmid, V., B. Schmid, B. Schneider, and G. Baker. 1976. Factors effecting manubrium-regeneration in Hydromedusae (Coelenterata). Roux's Archives of Developmental Biology. 56: 41-56.

Schmid, V., M. Wydler, and H. Alder. 1982. Transdifferentiation and regeneration in vitro. Developmental Biology. 92: 476-488.

Schneider, B. 1975. Die manubrium-regeneration bei der Leptomeduse Phialidium hemisphaericum: einfluss der ernafhrung und der gewebespannung. Diplomarbeit. Universität Zürich, Zürich.

Schnitzler, C.E. 2019. What makes a jellyfish. Nature Ecology \& Evolution. 3: 724-725.

Seipp, S., J. Schmich, T. Kehrwald, and T. Leitz. 2007. Metamorphosis of Hydractinia echinata-Natural versus artificial induction and developmental plasticity. Development Genes and Evolution. 217: 385-394.

Siebert, S., J.A. Farrell, J.F. Cazet, Y. Abeykoon, A.S. Primack, C.E. Schnitzler, and C.E. Juliano. 2019. Stem cell differentiation trajectories in Hydra resolved at single-cell resolution. Science. 365: eaav9314.

Siebert, S., and C.E. Juliano. 2017. Sex, polyps, and medusae: Determination and maintenance of sex in cnidarians. Molecular Reproduction and Development. 84: 105-119.

Singla, C.L. 1975. Statocysts of Hydromedusae. Cell and Tissue Research. 158: 391-407.

Sinigaglia, C., S. Peron, J. Eichelbrenner, S. Chevalier, J. Steger, C. Barreau, E. Houliston, and L. Leclère. 2020. Pattern regulation in a regenerating jellyfish. ELife. 9: 1-33.

Sinigaglia, C., D. Thiel, A. Hejnol, E. Houliston, and L. Leclère. 2018. A safer, urea-based in situ hybridization method improves detection of gene expression in diverse animal species. Developmental Biology. 434: 15-23.

Slautterback, D.B., and D.W. Fawcett. 1959. The development of the cnidoblasts of Hydra. an electron microscope study of cell differentiation. The Journal of Biophysical and Biochemical Cytology. 5: 441-452.

Steinmetz, P.R.H., J.E.M. Kraus, C. Larroux, J.U. Hammel, A. Amon-Hassenzahl, E. Houliston, G. Wörheide, M. Nickel, B.M. Degnan, and U. Technau. 2012. Independent evolution of striated muscles in cnidarians and bilaterians. Nature. 487: 231-234. 
Stidwill, R. 1974. Inhibitions-und induktionspheanomene bei der manubriumregeneration der leptomeduse Phialidium hemisphaericum (L.). Diplomarbeit. Universität Zürich, Zürich.

Takahashi, T., and M. Hatta. 2011. The importance of GLWamide neuropeptides in cnidarian development and physiology. Journal of Amino Acids. 2011: 1-8.

Takahashi, T., and N. Takeda. 2015. Insight into the molecular and functional diversity of cnidarian neuropeptides. International Journal of Molecular Sciences.16: 2610-2625.

Takeda, N., Y. Kon, G. Quiroga Artigas, P. Lapébie, C. Barreau, O. Koizumi, T. Kishimoto, K. Tachibana, E. Houliston, and R. Deguchi. 2018. Identification of jellyfish neuropeptides that act directly as oocyte maturation-inducing hormones. Development. 145: dev156786.

Tebben, J., D.M. Tapiolas, C.A. Motti, D. Abrego, A.P. Negri, L.L. Blackall, P.D. Steinberg, and T. Harder. 2011. induction of larval metamorphosis of the coral Acropora millepora by tetrabromopyrrole isolated from a Pseudoalteromonas Bacterium. PLoS One. 6: 1-8.

Technau, U., and M. Schwaiger. 2015. Recent advances in genomics and transcriptomics of cnidarians. Marine Genomics 24: $131-138$

Thomas, M.B., G. Freeman, and V.J. Martin. 1987. The embryonic origin of neurosensory cells and the role of nerve cells in metamorphosis in Phialidium gregarium (Cnidaria, Hydrozoa). International Journal of Invertebrate Reproduction and Development 11: 265-287.

Trembley, A. 1744. Memoires pour servir a l'histoire d'un genre de polyes d'eau douce, a bras en forme de cornes. Leide: Verbeek, Jean \& Herman.

Urdy, S. 2012. On the evolution of morphogenetic models: Mechano-chemical interactions and an integrated view of cell differentiation, growth, pattern formation and morphogenesis. Biological Reviews. 87: 786-803.

van der Sande, M., Y. Kraus, E. Houliston, and J. Kaandorp. 2020. A cell-based boundary model of gastrulation by unipolar ingression in the hydrozoan cnidarian Clytia hemisphaerica. Developmental Biology. 460: 176-186.

Vining, K.H., and D.J. Mooney. 2017. Mechanical forces direct stem cell behaviour in development and regeneration. Nature Reviews Molecular Cell Biology. 18: 728-742.

Weber, C. 1981. Structure, histochemistry, ontogenetic development, and regeneration of the ocellus of Cladonema radiatum Dujardin (Cnidaria, Hydrozoa, Anthomedusae). Journal of Morphology. 167: 313-331.

Webster, B.G., and S. Hamilton. 1972. Budding in Hydra: The role of cell multiplication and cell movement in bud initiation. Journal of Embryology and Experimental Morphology. 27: 301-316.

Webster, N.S., L.D. Smith, A.J. Heyward, J.E.M. Watts, R.I. Webb, L.L. Blackall, and A.P. Negri. 2004. Metamorphosis of a scleractinian coral in response to microbial biofilms. Applied and Environmental Microbiology.70: 1213-1221.

Weiler-Stolt, B. 1960. Über die bedeutung der interstitiellen zellen für die entwicklung und fortpflanzung mariner hydroiden. Roux's Archives of Developmental Biology. 152: 398-454.

Weismann, A. 1883. Die entstehung der sexualzellen bei den hydromedusen. Gustav Fisher. Jena.

Wikelski, M., and C. Thom. 2000. Marine iguanas shrink to survive El Niño. Nature. 403: 37-38.

Zeleny, C. 1907. The effect of degree of injury, successive injury and functional activity upon regeneration in the scyphomedusan, Cassiopea xamachana. Journal of Experimental Zoology. 5: 265-274. 